\title{
Al-Kindī’s braid
}

\author{
O. WRIGHT ${ }^{1}$ \\ School of Oriental and African Studies
}

Although known mainly as a philosopher, al-Kindī (d. c. 874) is also generally esteemed as the first major theorist of music in the Arab world. More precisely, he is the earliest writer in this field whose work has survived in sufficient quantity for some critical assessment to be made, even if the scope of his achievements has yet to be adequately evaluated. ${ }^{2}$ It is clear, nevertheless, that although his varied treatises reflect something of an indigenous tradition of theorizing, perhaps most obviously in his discussion of the rhythmic cycles, they are noteworthy above all for their incorporation of new learning, being representative of a dynamic period of development during which the assimilation into Islamic culture of the Greek legacy, whether in philosophy, medicine, science or mathematics, was to transform the intellectual landscape. Given the very novelty of this material it is hardly surprising to find, at least as far as music is concerned, that al-Kindi was less an original thinker than a transmitter-large-scale syntheses would come later.

In dealing with translated material he was confronted, inevitably, with a new technical vocabulary and the interpretative opportunities and pitfalls associated with it. His texts, in their turn, confront the modern reader with problems, some philological, others musicological. The surviving manuscripts are not always wholly reliable, and even where the reading is secure it may be difficult to discriminate between statements that bear on contemporary practice and others that are not relevant to it, forming as they do part of a process of intellectual appropriation. Considering both the state of the original text and the scholarly literature that has been generated by it, an attempt will be made here to investigate one such terminological and conceptual nexus; that dealing with the classification of melodic movement.

Under intiqāl ('transition, transfer, move, shift') in L. I. al Faruqi's (1981) An Annotated Glossary of Arabic Musical Terms are listed, amongst other things, four types of schematic melodic movement as defined by al-Kindì. The definitions given for the first three are seemingly straightforward, and correspond to those in the source text, the risāla fi khubr ta'lif al-alhān, ${ }^{3}$ with just the minor difference of the omission of the final return to the initial note that is specified for the third type. This is termed 'spiral' (lawlabi), and the omission has the incidental virtue of allowing the succession of expanding and contracting intervals that characterizes it to become fully apparent. Rather less visible, however, is the logic underlying the sequence of intervals in the fourth

${ }^{1}$ I am grateful to colleagues in the Department of Music at the School of Oriental and African Studies, who pointed to areas requiring clarification, and, especially, to Eckhard Neubauer, from whose penetrating comments I have derived much benefit.

${ }^{2}$ There has been no significant study subsequent to the general survey by Zakariyyā Yūsuf (1962b).

${ }^{3}$ The work is also referred to as risāla fì khubr șinäat al-ta'līf (Farmer, 1965: 9). Both Yūsuf Shawqī (1969: 29-31) and Zakariyyā Yūsuf (1962a) opt for this, but the reasons for doing so marshalled by Yūsuf Shawqī are insufficiently convincing to warrant dislodging the title used here, which is that cited in the colophon of the manuscript (British Library Or. 2361, fol. 168).

Bulletin of SOAS, 69, 1 (2006), 1-32. C School of Oriental and African Studies. Printed in the United Kingdom. 
type, where the first illustration beneath al Faruqi's general rubric of an 'interweaving of alternating large-small, ascending-descending intervals' is shown in Figure 1:

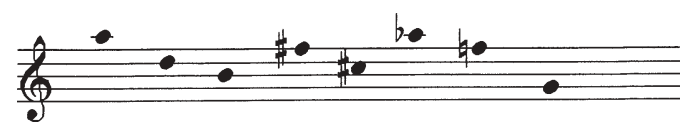

Figure 1.

Indeed, since al-Kindī informs us that such patterns can-and indeed should - be extended, this rather looks as if it is threatening to become a thoroughly twentieth-century 12-tone row. But just as puzzling as the angularity of the outline is the nature of the underlying pattern, for although fifths and thirds predominate one can hardly discern regularity in their disposition, despite the placing of a falling minor third after the first interval and before the last; and despite the rubric, the ascending (A) and descending (D) distribution of the intervals is certainly not alternating (although it does exhibit mirror symmetry: D D A D A D D). In short, the nature and function of this example are hard to fathom, and beyond the associated interpretative problems one may point to the more general question why a review of possible melodic structures, even one conducted by a speculative philosopher rather than a practising musician, should explore such a seemingly arcane and artificial arrangement of pitches.

The sources cited by al Faruqi in relation to this and the preceding descriptions are the edition, translation and study of al-Kindī's treatise by Yūsuf Shawqi (1969) and the translation by Cowl (1966), to which is appended a facsimile of the original manuscript (British Library Or. 2361, ff. 165-8); and in addition to these, consideration needs to be given to the edition of Zakariyyā Yūsuf (1962) and the earlier study by Lachmann and el-Hefni (1931), which includes an edition, a translation and a facsimile of the original manuscript. This is, unfortunately, the only surviving copy (Shiloah, 1979: 256-7), and a warning of likely interpretative problems to come is provided in the colophon by the frank admission of the scribe that his manuscript, finished on $17 \mathrm{rabi}^{\circ}$ al-thāni 1072/29 December 1662, was copied from one written in Damascus in late shawwäl 621/November 1224 which was in turn based on a copy ominously characterized as defective and unauthenticated (nuskha saqima ghayr mu'tamada). Given that the pitch set of Figure 1 is most peculiar when compared with those of the remaining types of melodic movement, one could well conclude in the light of this statement that it is the product of textual corruption. But before accepting what seems an open invitation to emend, it still seems prudent to explore a little further the potential of the wording as it stands, and to set it in context.

The first subject to be treated in this acephalic treatise is the description (shorn of its beginning) of a lute (' $\bar{u} d$ ) fretting producing a Pythagorean diatonic scale covering the two octaves of the Greek systema teleion plus an additional whole-tone (an extension caused by placing a disjunctive whole-tone between two complete octaves). Given this range, a notional fifth string is required, so that, representing the lowest pitch by $\mathrm{A}$, we have the plan laid out in Figure 2. 


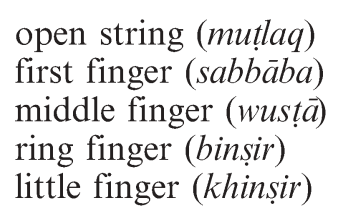

$\begin{array}{ccccc}\text { bamm } & \text { mathlath } & \text { mathnō } & z \bar{i} r & z \bar{i} r 2^{4} \\ \mathrm{~A} & \mathrm{~d} & \mathrm{~g} & \mathrm{c}^{\prime} & \mathrm{f}^{\prime} \\ \mathrm{B} & \mathrm{e} & \mathrm{a} & \mathrm{d}^{\prime} & \mathrm{g}^{\prime} \\ \mathrm{c} & \mathrm{f} & \mathrm{b} & \mathrm{eb}^{\prime} & \mathrm{a} b^{\prime} \\ \mathrm{c} \# & \mathrm{f} \# & \mathrm{~b} & \mathrm{e}^{\prime} & \mathrm{a}^{\prime} \\ \mathrm{d} & \mathrm{g} & \mathrm{c}^{\prime} & \mathrm{f}^{\prime} & \mathrm{b}^{\prime} \\ & & & & \mathrm{b}^{\prime}\end{array}$

Figure 2.

(This range will be rendered in notation by

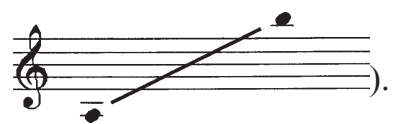

Reference is also made to pitches falling between the open string and the first finger fret, and their existence is implied by the sequence of letters used to designate pitch. Nevertheless, they are categorized as unused (mu'arrāh min al-isti'māl), and in this respect al-Kindi's account is congruent with the normative theory of contemporary practitioners as articulated by Ibn al-Munajjim (d. 912), which does not recognize a fret in this position (Neubauer, 1996: 268-9), ${ }^{5}$ as a result of which certain pitches in the lower octave are not replicated in the upper, and vice versa.

Al-Kindi begins the survey of melodic progressions by invoking a binary distinction between 'successive' (mutatālī) and 'non-successive' (lā mutatāl $\bar{\imath})$ movements. The latter is then divided into two types, the 'spiral' (lawlabì) and the 'sash' (muwashshah), although thereafter the second is no longer called 'sash' but 'braid' (dafir). We are informed, further, that there are two types of braid, the 'separate' (munfasil) and the 'interwoven' (mushtabik), ${ }^{6}$ and it is the latter that is represented in Figure 1. His treatment of the topic then unfolds in the form of a set of definitions for all the various categories followed by a block presentation of examples, so that in each case there are two types of evidence that should ideally be congruent and complementary. The structure of the interwoven braid is outlined in the first brief and rather cryptic description:

From the initial note one moves to another, then back to the area of the first, then to beyond its end, and so on until the notes of the group are used up, with the final move back to the beginning being a consonant one.

huwa al-mubtada' min naghma thumm yuntaqal minhā ilā ukhrā thumm yuntaqal minhā ilā dawr al-ūlà thumm yuntaqal minhā ilā khalf nihāyatih thumm kadhālik hattā yu'tā 'alà nagham al-jam' thumm takūn al-nuqla min äkhirih ilā mubtada'ih mu'talifa

The translation attempts to avoid interpretation as much as possible, and for dawr, commonly used in rhythmic analysis but not in this context a generally known technical term, the suggested rendition 'area' should be regarded as

\footnotetext{
${ }^{4}$ Referred to by later theorists as hādd, but by al-Kindī as zīr thānī ('second zīr') or zīr asfal ('lower zìr' - that is, higher in pitch but lower in position on the vertical plane of the face of the ' $\bar{u} d$ when played).

${ }^{5}$ For a translation of Ibn al-Munajjim's text see Neubauer (1996: 300-16).

${ }^{6}$ Later the text has the variant mushtarak ('shared, joint') in place of mushtabik. This also provides a satisfactory semantic contrast with munfasil, but there is no reason to prefer it to mushtabik, and it will not be considered further.
} 
tentative. ${ }^{7}$ But whatever its precise meaning, the logical implication of what precedes is that the second note lies beyond it, while the gender of the pronoun in 'its end' relates this phrase to it, so that the fourth note also presumably lies beyond it. We are given no clear indication here of what the size of the area might be, and although it might be thought that the matter had been settled in the preceding definition of composition ( $\sin \bar{a}^{t} a t$ al-lahn), where dawr is used to refer to a span of either an octave or a fifth, there is the complication that the term translated here as 'group', jam', which the context requires to be greater than dawr, is also usually associated with a set of notes comprised within a fifth or octave as well as within a larger interval (al-Kindì speaks at one point of a jam" of a double octave). ${ }^{8}$

Now, if we notate the 'area of the first' as $\{1\}$, and the notes yielded by the successive moves as 2, 3 and 4 respectively, the various possible combinations derivable from this description are given in Figure 3.

$\begin{array}{ll}\{1,3\} 2,4 & 4,2\{3,1\} \\ \{1,3\} 4,2 & 2,4\{3,1\} \\ \{3,1\} 2,4 & 4,2\{1,3\} \\ \{3,1\} 4,2 & 2,4\{1,3\} \\ 4\{1,3\} 2 & 2\{3,1\} 4 \\ 4\{3,1\} 2 & 2\{1,3\} 4\end{array}$

Figure 3.

(That is, there are six possible configurations, each of which can proceed in either an ascending or a descending direction.) But without additional evidence it is impossible to go further than establish the obvious: that we are dealing here with a clearly disjunct zigzag pattern.

For that evidence it is to the relevant example that we need to turn. The examples as a group are prefaced, as a comprehension aid for the learner (li-yakūn ashadd taqrīban li-fahm dhālik min anfus al-muta'allimīn), by a diatonic octave given in alphabetic notation, the letters arranged in the abjad order:

$\begin{array}{llllllll}\bar{a} & j & d & w & h & t & k & \bar{a} \\ \mathrm{~A} & \mathrm{~B} & \mathrm{c} & \mathrm{d} & \mathrm{e} & \stackrel{\mathrm{f}}{\mathrm{g}} & \mathrm{a} .\end{array}$

For the more complex interwoven braid, however, a canvas larger than that provided by a single diatonic octave scale seems to have been required, and al-Kindī prefaces his example with an elucidatory three-line grid of pitches which extends the range to just over two octaves. But it is not simply a

\footnotetext{
${ }^{7}$ Yūsuf Shawqī (1969: 69-70) renders dawr by 'tonal progression', and clarifies this as meaning a succession of notes in a particular order covering a fifth, an octave, or more, which seems to read into the text more than is justified, and is either too vague or too specific to be helpful here. (His following comment to the effect that al-Kindî's use of the term sheds light on the origin of the modern dawr form is just a rather sad example of wishful thinking.) Lachmann and el-Hefni (1931: 28) render it by 'Kreis', their translation of the relevant passage being: '... dann von ihm zum Kreis des ersten Tons, dann von ihm zu dem, der hinter dem Grenzton des Kreises liegt ...'. Cowl (1966: 147), likewise, opts for 'circle', but manages to produce a version making little sense: '... then from that onto a circle of the first; then it moves beyond the limit of the circle; and so on until it comes back to the unit tones'. 'Kreis (or Kreislauf)/circle' are more helpful translations when it comes to the descriptions of the spiral forms, where dawr is suggestive of movement.

${ }^{8}$ Dawr is also used in a quite different sense elsewhere in the Risāla, denoting, in a straightforward semantic extension of its primary meaning of 'circle', a form of cyclical movement (in relation to a concluding return to the modal tonic/finalis (ya'üd dawr al-lahn ilä martabatih)).

${ }^{9}$ In the abjad order the letters may function as numerals. The scale given thus corresponds to 1 , $3,4,6,8,9,11,1$ ', implying therefore in relation to the lute fretting the existence of the unused intervening pitches B), ct, e), $\mathrm{f}$, a. That we are dealing here with an abstract concept is demonstrated by the fact that the lute fretting provides this set of 12 pitches neither in the lower octave (where $\mathrm{B}$;, e), and a are missing) nor in the upper (where $\mathrm{c}^{\prime \prime}$ and $\mathrm{f}^{* \prime}$ are missing).
} 
restatement of the pitches produced by the fretting of the (theoretical) fivestring lute given above. It fails, on the one hand, to include the $b^{\prime}$ which lies beyond the highest fret of the fifth string, while on the other hand it includes, unexpectedly, additional pitches that would require extra frets between open string and first finger fret, precisely, therefore, those pitches which he had previously categorized as unused. Also to be noted is that these extra pitches are not systematically included throughout: the two that would have related to the lower strings are omitted. The grid is given in Figure 4 with, above, al-Kindī's own alphabetic notation, in which the letters, again arranged in the abjad order, go up to $l$ and then repeat at the octave.

$\begin{array}{llllllll}\bar{a} & j & d & h & w & h & t & y \\ \mathrm{~A} & \mathrm{~B} & \mathrm{c} & \mathrm{c} & \mathrm{d} & \mathrm{e} & \mathrm{f} & \mathrm{f}^{\sharp} \\ k & l & \bar{a} & b & j & d & h & w \\ \mathrm{~g} & \mathrm{a} b & \mathrm{a} & \mathrm{b} b & \mathrm{~b} & \mathrm{c}^{\prime} & \mathrm{c}^{\prime} & \mathrm{d}^{\prime} \\ z & h & t & y & k & l & \bar{a} & b \\ \mathrm{e} l^{\prime} & \mathrm{e}^{\prime} & \mathrm{f} & \mathrm{f}^{\prime \prime} & \mathrm{g} & \mathrm{a} l^{\prime} & \mathrm{a}^{\prime} & \mathrm{b} b^{\prime 10}\end{array}$

Figure 4.

It is followed immediately by the example for the interwoven braid:

It is like our going from the high $\bar{a}$ to the first $w$, then from $w$ to the first $b$, then from $b$ to the first $y$, then from $y$ to $h$, then from $h$ to $l$, then from $l$ to the first $t$, then from $t$ to the second $k$, and so on until the braid is complete, after which there is a return to the initial note.

ka-'ntiqālinā min à al-hādda ilā $w$ al-ūlà thumm min $w$ ilā $b$ al-ūlā thumm min

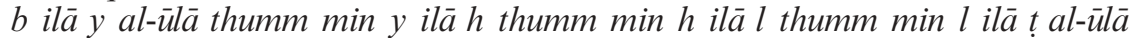
thumm min țilā $k$ al-thāniya wa-kadhālik ilà hayth yatanāhā al-dafìr thumm al-'awd ilā al-mubtada'.

But this in its turn presents problems of interpretation. The 'high $\vec{a}$ ' could be either a or a', and the 'first $w$ ' could be either $d$ (the first encountered when starting from the lowest pitch in the grid) or d' (the first encountered when ascending from a or descending from $\mathrm{a}^{\prime}$ ), and so on. But assuming only that 'first' is used consistently, the example at least accords with the description to the extent that under most conditions it fits, beyond the seemingly arbitrary (because undefined) initial move from one note to another, the first explicit indication of direction: the move from the first $w$ (whether $\mathrm{d}$ or $\mathrm{d}$ ') to the first $b$ (b), not bi', according to the above criteria) constitutes a return to the area of the first note, if a, and likewise if the first note is a' and 'first' is understood to mean 'the first encountered when descending from the highest pitch in the grid', yielding therefore b ${ }^{\prime}$ '. According to the description the next note, the first $y$ ( $f *$ or $f$ '), should lie 'beyond the end' of 'the area of the first' but, as noted above, the extent of that area is vague, and the meaning correspondingly unclear. However, assuming that, in the case of a, 'the area of the first' does not go below $g$ then $f$ is safely beyond it, example and description are in accord, and we have the shape $4\{1,3\} 2$. (In the case of initial a' 'the area of the first' would also need not to go below g' for f"' to be beyond it, which seems intrinsically less likely. The resulting shape would be $2,4\{1,3\}$.)

Beyond this point the description ceases to be specific, and of itself appears insufficient to establish the rules of the game (assuming these to involve

${ }^{10}$ Yūsuf Shawqī unaccountably omits the fourth column of this table from his edition (1969: $110)$, despite including it in his translation (p. 24 of the English pagination). 
recursivity). Setting aside the final instruction to return to the beginning, out of the repertoire of 24 pitches contained in the grid it specifies the directional relationships between no more than four. If we abstract from the example the more likely shape $4\{1,3\} 2$, the grid slots used will be $11,16,12$ and 8 , i.e. the moves are $+5,-4$ and -4 , and if these are continually repeated (beginning from $\left.f^{*}\right)$ only twelve pitches are exhausted before the series goes off the grid.

The example, though, goes on with a further four notes which ought to help show how the movement is supposed to continue, and discussion of these may appropriately be combined with a consideration of previous scholarship, for it is on the examples that this has generally concentrated. It is, in fact, to the example of the interwoven braid that the notation taken from al Faruqi (Figure 1) relates, as does that provided by Zakariyyā Yūsuf (Figure 5), and likewise that of Yūsuf Shawqī (Figure 6).

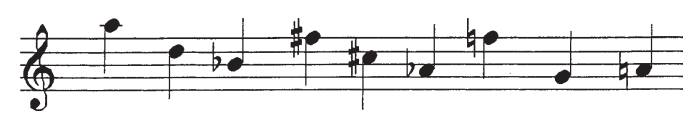

Figure 5 .

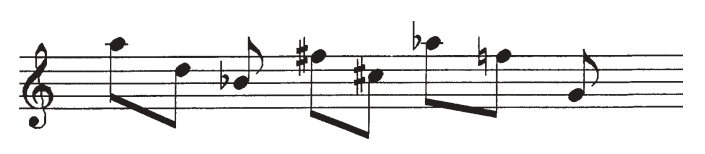

Figure 6.

All three demonstrate an evident family resemblance. Indeed, apart from the $b$ in al Faruqi (possibly a slip) in place of the b) in the other two, and the addition of a final a in Zakariyyā Yūsuf, the only difference concerns a single disagreement as to which is the correct octave: the varying choices to omit or include stems and beams are purely cosmetic. ${ }^{11}$ (The final a in Zakariyyā Yūsuf, even if an octave below the first a', is presumably a response to the textual requirement of a final return to the initial note.)

Despite such broad unanimity, these versions are by no means the only ones possible, for the pitches specified in them are just one or two among the potentially multiple combinations supplied by the grid. The logic justifying the first four and the final two notes in Figures 1, 5 and 6 appears to be:

(a) the initial 'high $\vec{a}$ is a';

(b) 'first' means 'the first encountered when descending from a'.

However, there are two possibilities for $h$, c and $c^{\ddagger}$, and two for $l$, a and $a v^{\prime}$, concerning which the text is not specific, ${ }^{12}$ so that the choice of $c^{\prime \prime}$ is arbitrary, as is that of a by Zakariyyā Yūsuf and al Faruqi and av' by Yūsuf Shawqī; and to consider just one other approach, one could proceed as follows:

(c) the initial 'high $\vec{a}$ ' is a or a';

(d) 'first' means 'the first encountered when ascending from the lowest pitch in the grid';

and arrive with an equally logical consistency at the version shown in Figure 7.

${ }^{11}$ As is shown by the fact that Yūsuf Shawqi repeats the notation in his commentary (1969: 184-5) with a different disposition of beams (intending thereby to make a structural point).

${ }^{12}$ In each case Cowl (1966: 147) adds 'first' to his translation. 


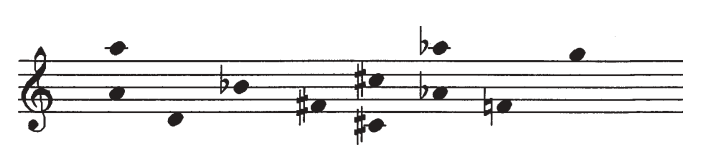

Figure 7.

But this still leaves us with the problem of choosing between the various octave alternatives, and thence of defining the particular pattern which should be continued 'until the braid is complete'.

It might be hoped that reference to the parallel description and example of the other type, the 'separate' (munfasil) braid, would help resolve this difficulty, but here too the situation seems problematic. As before, we are given first a description, again translated here in a painfully literal way:

From the initial note one moves to another, then back to the area of the first, then to a note going beyond the second, then to a note going beyond the second which lies between the second and that from which one has moved, then from this again to one going beyond that from which one has moved, until all the notes of the group are used up, with the final move back to the beginning being a consonant one.

yubtada' min naghma thumm yuntaqal minhā ilā ukhrā thumm yuntaqal minhā ilā dawr al-ūlā thumm yuntaqal minhā ilā khārij[a] min al-thāniya thumm yuntaqal minhā ilā khārij[a] min al-thāniya taqa' fimā bayn althāniya wa-'llatī 'ntuqil minhā thumm yuntaqal minhā ilā khārija 'an allatī 'ntuqil minhā aydan hattā yu'tā 'alā ākhir nagham al-jam' wa-takūn al-nuqla min ākhirih ilā 'btidä' al-nagham nuqla mu'talifa.

Although at first glance this appears to be even more impenetrable than the previous description, ${ }^{13}$ it is actually possible to derive from it a coherent set of instructions. Given that the first two moves are defined in exactly the same way as for the 'interwoven' type, they may be represented, employing the same notation as before, by $\{1,3\} 2$, and the following moves would expand this successively to $\{1,3\} 2,4$ then $\{1,3\} 2,5,4$ and then either $\{1,3\} 2,5,4,6$ or $\{1,3\} 2,5,6,4$ (in both cases either ascending or descending). Again, as before, it makes sense at this point to see whether the related example can shed further light on the intended structure. In fact, comparison between the examples provided for the two braid types suggests that despite the more convoluted nature of its description the separate braid may have been perceived by al-Kindi to be a less complex entity, for we find that, as the text stands, its basic form is captured in the example by six notes as against the preceding eight, and certainly the semantic contrast between the terms munfasil and mushtabik would support the case for the former being somehow the simpler. The example is as follows:

${ }^{13}$ The version given by Cowl (1966: 147) is equally opaque: 'The unbound [Cowl's rendering of munfasil] begins with any tone; then proceeds from it to another; then from that one to a circle of the first; then from there to one adjacent to the second. The next tone falls between the second and what is beyond (the second); then back again to the adjacent tone; and continues thus until .... It also omits a phrase repeated in the original, taking its cue, presumably, from the edition of Lachmann and el-Hefni or from that of Zakariyyā Y ūsuf, both of which excise one occurrence of thumm yuntaqal minhā ilā khārij[a] min al-thäniya, and Yūsuf Shawqī was later to do the same in his edition. Although dittography may reasonably be suspected, it is extraordinary that a case for it is never made, in other words the passage is nowhere demonstrated to be impossible (rather than merely obscure) as it stands. 
It is like beginning from the high $[\bar{a}]$ and moving to the first $w$, then moving from $w$ to $j$, then from $j$ to the first $y$, then from $y$ to the first $h$, and then from $h$ to the second $\bar{a}$.

ka-'l-ibtidā' min [ā] al-hāadda wa-'l-intiqāl ilā $w$ al-ūlà thumm al-intiqāl min $w$ ilā $j$ wa-min j ilā y al-ūi $\bar{a}$ wa-min y ilā ḥ al-ūlā wa-min ḥilā à al-thāniya

Considered in relation to the grid, the same problems of direction and selection arise. If we operate according to the logic that seems to underlie Figures 1, 5 and 6 , and follow the general consensus that the unidentified first note is a', we will have $\mathrm{a}^{\prime} \rightarrow \mathrm{d}^{\prime} \rightarrow \mathrm{B}$ or $\mathrm{b} \rightarrow \mathrm{f}^{\prime \prime} \rightarrow \mathrm{e}^{\prime} \rightarrow \mathrm{a}$, and this is, indeed, the conclusion arrived at by al Faruqi, Zakariyyā Yūsuf and Yūsuf Shawqī, whose versions are all slightly different presentations of the series of pitches shown in Figure 8.

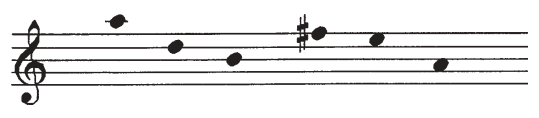

Figure 8.

However, according to the alternative approach offered above we could just as well have $\mathrm{a}^{\prime} \rightarrow \mathrm{d} \rightarrow \mathrm{B}$ or $\mathrm{b} \rightarrow \mathrm{f} \rightarrow \mathrm{e} \rightarrow \mathrm{a}$. This may be regarded as intuitively less likely, but it does not follow that the former solution is the only valid one, especially as its attractiveness is diminished by the fact that it does not accord with the description, failing to satisfy the requirements of the moves. Thus even with $\mathrm{b}$ in preference to $\mathrm{B}$, it is impossible to understand the move $\mathrm{d}^{\prime} \rightarrow \mathrm{b}$ as being 'back to the area of the first', while f" can only be 'beyond the second' if this phrase is understood to mean 'higher in pitch', which goes against the grain of selection according to a descending principle. In general, instead of $\{1,3\} 2,5,4,6$ or $\{1,3\} 2,5,6,4$ we seem to have moves that could be represented as $\{1,5,4\} 2,3,6$. With both types of braid we thus arrive at an impasse: either the example produces an apparently illogical set of pitches and/or there is incompatibility between what the definition seems to require and what the example seems to provide. Neither example yields a readily discernible pattern that could be used either as a reliable check on the text of the initial descriptions or, more interestingly, to continue the series to its logical conclusion, and as a result it is difficult to derive from them answers to the questions raised by the grid of potential pitches.

But that the problem may lie with the processes of deduction that have led to such an unsatisfactory conclusion rather than with the original text is suggested both by the ease with which the preceding material can be understood and by the uncomplicated and wholly convincing nature of the resulting structures. For the simplest movement, the 'successive' (mutatālì), the description given is:

The successive is like beginning from a given note and proceeding in a direct line upwards or downwards in pitch.

ammā al-mutatālì fa-ka-'l-ibtidä' min naghma thumm al-tazayyud fì 'l-hidda aw al-thiqal 'alā 'stiqāma.

This seems already sufficiently clear, but the ground is gone over again in the examples section where, immediately after the prefatory octave scale, the successive steps of simple up and down scalar progressions are patiently spelled out. To be noted, however, is the degree of editorial intervention to which this 
passage has been subjected by both Zakariyyā Yūsuf and Yūsuf Shawqī in order to extract from it ascending and descending scales covering the whole octave, and in fact it would require fewer and less radical emendations to read it as yielding:

$\begin{array}{llllllll}\text { A } & \text { B } & \text { c } & \text { d } & \text { e } & \text { f } & \text { g } & \text { A } \\ \text { A } & \text { g } & \text { f } & \text { e } & \text { d } & \text { c } & \text { B } & \text { A }\end{array}$

involving in each case a return to the initial note, a feature which has the attraction of creating a structural parallel between the mutatāli type and the others, to the definitions of which such a return is integral. (At the same time, it could be argued that this reading is weakened somewhat by its failure to include the upper note of the preceding octave scale. $)^{14}$

But even if slight interpretative variations can be entertained, the sense of the mutatāli category is clear, and the same is true for the descriptions and matching examples of the other non-successive structure, the 'spiral' (lawlabi). Here, again, two types are distinguished, the 'inward' (däkhil) and the 'outward' (khärij), stated to be progressions such that, given e.g. the pitch set $p$... $p+n$, the former produces $p, p+n, p+1, p+(n-1) \ldots$ (and then back to $p$ ), while the latter moves in the reverse direction. These movements are subsequently exemplified by:

$\begin{array}{llllll}\text { 'inward' spiral: } & \text { A } & \text { e } & \text { B } & \text { d } & \text { A } \\ \text { 'outward' spiral: } & \text { d } & \text { B } & \text { e } & \text { A } & \text { d }\end{array}$

In each case, then, we have an outline which matches the description perfectly. ${ }^{15}$ But if such correspondences may be deemed to validate the text, the resulting note sequences raise in their turn the question of the nature of the entities being presented here, for even though the preceding ascending and descending scales offered in illustration of the principle of conjunct motion might certainly be thought of as abstractions, it may still be assumed that they could have been extrapolated from the basic processes of contemporary melodic creation, whereas such an assumption could less readily be made on behalf of the examples supplied for the spiral formations. It is instructive, for example, that Shawqi (1969: 180) can best make sense of them by interpreting them not as free-standing melodic structures but as a scaffolding of framing notes indicating the points at which the melody changes direction, so that e.g. the example of the 'inward' spiral might generate A B c d e d c B c d c B A.

\footnotetext{
${ }^{14}$ The original runs: ka-'ntiqālinā min à ilā $j$ wa-min j ilā $d \ldots$ wa-min $k$ ilāa à al-m.b.t.d + gap + min

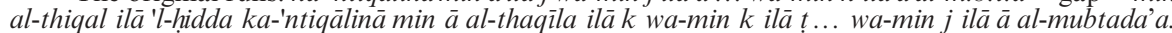
$a l-m . b . t . d$, is obviously to be read as a truncated form of al-mubtada'a, but both Zakariyyā Yūsuf (1962a: 62) and Yūsuf Shawqī (1969: 109) (if with incidental variations for the phrase as a whole) insert bi-l-kayfiyya in the gap, understanding thereby the upper octave a, which then forces them to continue by reversing the directional terms: [aw] min al-hidda ila 'l-thiqal and then, consequently, to substitute min à al-hädda for min à al-thaqūla (Yūsuf Shawqī's note 8 should be corrected to: fì 'l-nuskha: al-thaqīla). Lachmann and el-Hefni (1931: xviii) also fill the gap with bi-l-kayfiyya $a w$, but then fail to follow the logic by not reversing the directional terms. They also keep $\vec{a}$ al-thaqila, so that their version of the second scale is exactly that proposed here, beginning A g and then descending. In contrast to previous editions, the interpretation suggested here requires nothing beyond the simplest of gap fillings (although this, it may be objected, is paradoxically a weakness, since a gap is more likely to relate to an unreadable rare term than to something obvious) and the later insertion of the conjunction wa- (or aw): ka-'ntiqālinā min à ilä $j$... ilä à al-mubtada'a [wa-hādhā] min al-thiqal ilā 'l-hidda [wa-] ka-'ntiqālinā min à al-thaqūla ilā $k$ wa-min $k$ ilā $t$... ilā $\bar{a}$ al-mubtada'a.

${ }_{15}$ Except in one detail. According to the description (both in the original and the various editions) the general evolution of the 'outward' spiral should proceed in an upwards direction, as the final note before the return to the beginning is defined as the highest (yantahi ila ahadd nihäyatay al-jam ). The example, on the other hand, proceeds downwards. The contradiction may be resolved be reading ihdā in place of ahadd, which would allow movement in either direction.
} 
In seeking to answer this question it is pertinent, first, to consider the nature of al-Kindī's musical output as a whole, and to note as one prominent strand within it the presence of material showing an interest in, and an awareness of, practical issues. We are thus provided, for example, with a description - the earliest extant - of the rhythmic cycles, ${ }^{16}$ and detailed information on the lute, covering materials, dimensions, fretting and tuning (Shiloah 1974; Neubauer 1993). ${ }^{17}$ Accordingly, given that the risāla fì khubr ta'lif al-alhān outlines a set of diatonic modes that may be correlated with (or are at least not readily distinguishable from) at least some of those partly defined in the treatise by Ibn al-Munajjim (Neubauer 1994: 401-02), representative of what Farmer has felicitously termed practical theory, it could be argued that however schematic the various spiral and braid structures may be the possibility should nevertheless be entertained that they are in some way derivable from the compositional processes of contemporary musicians. On the other hand, despite its domestication of the treatment of pitch through projection onto the fingerboard of the lute, it is clear that the risāla fi khubr ta'lif al-alhän should be classed as an exemplary manifestation of the early Abbasid enterprise of translating, adapting and developing the classical intellectual heritage, and that its tenor is fundamentally abstract and speculative rather than empirical and descriptive.

In other treatises cosmological ideas may come to the fore, but in the risāla fì khubr ta'līf al-alhān al-Kindī's clear indebtedness to Greek ideas is expressed within the domain of a theoretical exposition of pitch relationships. In its general organization one may see, perhaps, a loose resemblance to the treatise by Cleonides. This treats in order 'notes, intervals, genera, scales, tonoi, modulation and melic composition' (Strunk 1998: 36), followed by comments on ethos, whereas the risāla could be summarized in a similar vein as covering intervals, the disposition of notes on the lute, the disposition of the tetrachords, modes, and melodic structure (including modulation), followed by comments on ethos. But even assuming the morphological similarity not to be fortuitous, it is clear that this particular treatise could not have served as the immediate model for al-Kindī, and the transmission history is too obscure to allow his sources to be pinpointed. Nevertheless, Greek derivations are apparent at various levels: in some of the terminology al-Kindi uses for notes (e.g. wust $\bar{a}$ 'middle' < mesê) and the classes of tetrachord (e.g. lawnī 'coloured' = chromatic); in the layout of the tetrachords; in his conceptualization of mode; and in the following discussion of modal alterations within which fleeting reference is made to shifts from diatonic (tanīnì) to chromatic (lawnī) to enharmonic ( $\left.t^{\prime}{ }^{\prime} \bar{l}_{f} \hat{\imath}\right)$ tetrachord species, the last being especially revelatory as it was quite alien to contemporary practice - indeed, al-Kindi’s own lute fretting was incapable of producing it.

When we turn to the demonstration of modal structures, we must likewise recognize that the hypothetical fifth string reflects, rather than any extension of indigenous scalar norms, the need to incorporate (an extended version of) the Greek systema teleion. Equally significant is al-Kindî's choice of modal vocabulary. Avoiding both the mutlaq fì majrā al-wusța ('open string in the course of the middle finger') type of lute-fret designation used by transmitters of the Ishāq al-Mawșili school and any other jargon that may have been current among practising musicians (Neubauer 1994: 397-407; 1996: 268-74), al-Kindī underlines his indebtedness to Greek concepts by referring to

\footnotetext{
${ }^{16}$ In risāla fì ajzā' khubriyya fì 'l-mūsīqū (Zakariyyā Yūsuf 1962a: 97-8).

${ }^{17}$ In risāla fí 'l-luhūn wa'l-nagham (Zakariyyā Yūsuf 1962a: 111-20).
} 
$\operatorname{tanin}(\bar{a} t)($ 'mode $(\mathrm{s})$ ' $(<$ tonos $))$ and to jawānib ('sides'), a term unique to him which is evidently a calque of plagia (Neubauer 1994: 398). Nevertheless, the fact that diatonic tetrachords rather than, say, chromatic are used for purposes of demonstration could be seen as a genuflection to contemporary practice, and the contrast in approach reflected in the selection of different labels does not of itself elucidate the nature of the relationship between the modes as defined by al-Kindī and those of Ishāa al-Mawsilì as reflected by Ibn al-Munajjim. It is possible, in fact, to argue that this was quite close, and that al-Kindī's account might even subtend an eighth mode (Neubauer 1994: 400); equally, though, the presumed resemblances could be explained as no more than the inevitable but adventitious result of taking as tonic the successive pitches of a diatonic scale. Intriguingly, al-Kindi refers later to those who hold that there are three, four, six, thirteen and fifteen modes, but it is striking that he makes no mention of the system of eight which appears to have predominated among contemporary practitioners, and this again indicates that his own approach was elaborated independently and was based on different sources. ${ }^{18}$

Given this fundamentally Greek orientation of the risāla it is hardly surprising to find al-Kindi begin his survey of melodic progressions by invoking a binary distinction between 'successive' (mutatālì) and 'non-successive' (la mutatālà) echoing that expounded by Aristides Quintilianus between agogge (equivalent to 'conjunct' or 'successive') and ploke (equivalent to 'disjunct' or 'transilient') (West 1992: 191; Barker 1989: 418). Further, the latter term, translatable as 'plaiting' ${ }^{19}$ provides a precise terminological antecedent for dafir. But beyond that the pattern of resemblance is less exact, the derivation less clear, and al-Kindi has no equivalent to the three-fold taxonomy offered by Aristides Quintilianus. What correspondences there are may be displayed thus:

$$
\text { agōgē pettaia plokē }
$$

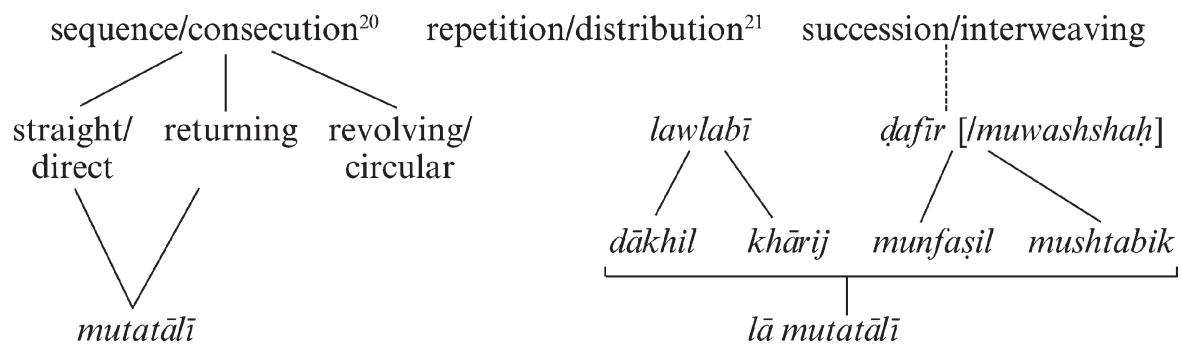

Thus although plokē comprises gapped progressions (Strunk 1998: 65), ${ }^{22}$ al-Kindī's lā mutatālī, which distinguishes spiral from braid types, with each subdivided, goes considerably further in its specificity than extant Greek theoretical literature, where the concept of disjunct movement is developed to the

\footnotetext{
${ }^{18} \mathrm{He}$ was, however, perfectly well aware of the Byzantine octoechos, referring to this in his risäla fì 'l-luhūn wa'l-nagham (Neubauer 1994: 378).

19 The meanings given in Liddell and Scott are: 'twining, twisting; anything twisted or woven, web; interweaving'.

${ }^{20}$ In each case the first term is the translation offered in Strunk (1998: 65), the second that by Barker (1989: 431).

${ }^{21}$ This appears to deal with the general concept of selection: the omission, inclusion and relative prominence of pitches.

${ }^{22}$ It is further defined in a fairly generic manner as follows (Barker 1989: 431): 'Interweaving projects a single sound across two or more intervals or notes by leaps ... and in this way produces a melody'. Thus there is no suggestion at this stage of a codification of specific shapes or types of progression.
} 
extent of recognizing, in Ptolemy's use of the terms anaploke and kataploke e, a generic directional subdivision (West 1992: 191), ${ }^{23}$ but not beyond. It would thus appear that al-Kindī either took over a later and unrecorded evolution of the ploke metaphor resulting in further subdivisions, or was himself prompted by a literal translation to elaborate new hypothetical disjunct (or combined conjunct and disjunct) possibilities of pitch organization.

We are thus unable to pinpoint the origin of the spiral concept. ${ }^{24}$ Nevertheless, accepting that the schematic treatment of melodic movement in the risāla represents an appropriation and/or elaboration of Greek categories does at least make the unexpected contours of the examples less problematic: it means that they no longer need to be interpreted, following Shawqī, as coded representations of whatever we might imagine aspects of contemporary Abbasid practice to have been, but may be viewed, instead, as autonomous entities that are essentially intellectual constructs. What they suggest is less a putative melodic type than a spatial projection, for the nature of the ever narrowing or widening intervals (in the 'inward' or 'outward' subcategories respectively) can most clearly be comprehended, as was already recognized by Lachmann and el-Hefni (1931: 12), in the visual, diagrammatic form shown for the inward in Figure $9^{25}$ and the outward in Figure 10.

Conceived in these terms the structures are logical, and descriptions and examples match perfectly. So far, then, al-Kindī's text has been clear and comprehensible, with relatively few scribal errors to impede interpretation. This suggests that in what follows it should be presumed to be reliable unless

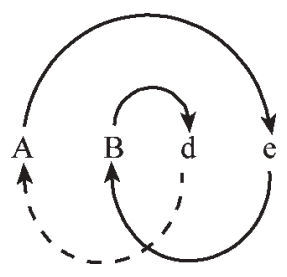

Figure 9.

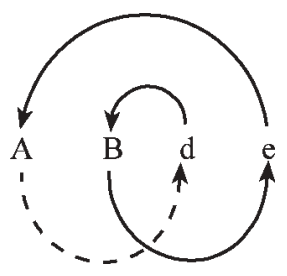

Figure 10.

\footnotetext{
${ }^{23}$ As well as being the opposite of anaploke, defined as a 'progression of notes ascending in scale', kataploke has the meaning 'entwining, interlacing'. For a translation of Ptolemy's text see Barker (1989: 341-2), where we again encounter the general 'melodic interweaving that proceeds through notes some distance apart'. A further term is symploke ('weaving together'), which Barker suggests might be a combination of the other two, adding, however, that it was 'perhaps merely the smooth melodic connection of notes widely spaced in pitch'.

${ }^{24}$ The sensible suggestion has been made (WKAS, s.v. lawlabī) that it might derive from a calque of heliktos, but this does not appear to be attested as a technical term in music.

${ }^{25}$ Zakariyyā Yūsuf (1962b: 16) arrives, presumably independently, at the same shape, but with the return not differentiated, so that the spiral is partially disguised. Cowl (1966: 136) reproduces, without acknowledgement, all the geometric figures proposed by Lachmann and el-Hefni.
} 
demonstrably not; and from the simplicity of the essentially visual spiral shapes it may be concluded that the two braid structures, even if not necessarily quite as elementary, ought also to be essentially straightforward and easily discernible patterns of repetition providing, if not convincing melodic movements, then at least attractive and internally consistent shapes. It is exactly such a formation that Lachmann and el-Hefni (1931: 13) propose for the separate braid (see Figure 11). This captures well the kind of shuttling motion that al-Kindī presumably had in mind: it has a pleasing symmetry; and typologically it is intuitively satisfactory as a solution. But even if on the right track, it is difficult to accept as a wholly accurate representation. Its shape is derived by drawing through the points made up of a descending series of notes:

$$
\begin{array}{llllll}
a^{\prime} & f^{\prime \prime} & e^{\prime} & d^{\prime} & b & a
\end{array}
$$

which accordingly occur in the order $a^{\prime} d^{\prime} b f^{\prime \prime} e^{\prime} a$, that is, it selects exactly those pitches which will later appear in the notated forms summarized in Figure 8, of which it may be regarded as the (largely unacknowledged) progenitor. ${ }^{26}$ Thus although it has the virtue of pointing to an inner logic in a way the notations do not, as an interpretation of the text it displays exactly the same strengths and weaknesses. Even considered in purely visual terms it could be argued that it is not wholly convincing, for its symmetry depends on the notes being equidistant: recognition of variations in interval size within the pentatonic scale used, or alternatively the insertion along the horizontal axis of intermediate pitches, whether of a diatonic scale or of those available in the grid, would require some of the curves to be distended. ${ }^{27}$

This last objection, however, may be dismissed. As a matter of general principle there would be nothing untoward about the notes, and likewise the intervals between them, being regarded as conceptually equivalent and therefore being represented as spatially equidistant. As for a possible relationship to the grid, it is true that al-Kindi uses exactly the same designations (high, first, second) as in the previous example, that of the interwoven braid, so that it seems natural to think in terms of the same set of pitches, especially as the notes used are not all found within the diatonic scale set at the head of the examples, but the fact remains that according to the grammar of the passage the grid was explicitly designed to facilitate a working out of the interwoven variety: in other words, although the notes of the separate braid may be found there, they do not necessarily function in relation to it, and indeed appear not to. In any case, reference to the grid would not lead to any clearer understanding of a sequence which could be further extended, for within it the pitches in question are $23,16,13,20,18$ and 11 , i.e. the moves are $-7,-3,+7,-2,-7$, and

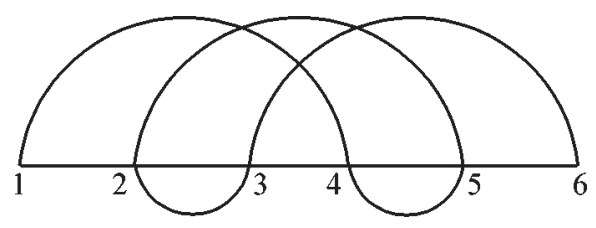

Figure 11.

${ }^{26}$ The one later scholar fully to recognize the work of Lachmann and el-Hefni is Yūsuf Shawqī (1969: 183-5).

${ }_{27}$ A point recognized by Lachmann and el-Hefni themselves (1931: 14). 
if continued the series would go off the grid before using up all the notes. This line of argument seems quite unproductive, and there would be just as little to be gained by hypothesizing a two-octave diatonic pitch set from A within which the example specifies pitches $15,11,9,13,12$ and 8, i.e. the moves are $-4,-2,+4,-1$ and -4 and if repeated they would simply produce the same pentatonic set in the lower octave.

The solution proposed by Lachmann and el-Hefni thus has the sought-for virtues of structural sobriety and credibility, and its symmetry also counts in its favour, but it ultimately fails to reconcile the example with the description. However, as there is a quantitative match between them that can hardly be fortuitous (the description defines five moves, the example six pitches), it is worth reconsidering whether they really are as irreconcilable as has hitherto been assumed. Examination of the description led to the conclusion that the moves involved could have been either $\{1,3\} 2,5,4,6$ or $\{1,3\} 2,5,6,4$ (either ascending or descending), but as the asymmetry of the changes of direction in the second makes it less attractive as a potential series we may prefer to attend to the potentialities of the first. Relating this to a set of successive pitches we may derive from it a presumably recursive $+2-1+3-1+2$ sequence of moves in ascent (or $-2+1-3+1-2$ in descent) which, projected visually, yields a simple series of loops. Specifically, if we restrict ourselves to the pentatonic precipitate of the pitches identified in the example, we would have

$\begin{array}{llllllll}\text { either: } & \text { A } & \text { d } & \text { B } & f^{*} & \text { e } & \text { a } & \ldots \\ \text { or: } & \mathrm{a}^{\prime} & \mathrm{e}^{\prime} & \mathrm{f}^{\prime} & \mathrm{b} & \mathrm{d}^{\prime} & \mathrm{a} & \ldots\end{array}$

Clearly, the descending alternative cannot be reconciled with the example. We may certainly take the initial 'high $\vec{a}$ to mean a', and thereafter understand e.g. 'the first $w$ ' to mean 'the first $w$ to occur in the grid when descending from a'. We may also understand by $j$ b rather than $\mathrm{B}$, but the end result is the familiar a' d' b f"' e' a: the order is scrambled, and the simple loops disappear. In the ascending version, on the other hand, the order is as in the example, and except for the initial A the notes as defined there can be assigned to the correct octave by reversing the previous directional rule, so that we have:

'first $x$ ' means 'the first instance of $x$ encountered in ascending from the lowest pitch'

which is in any case intuitively preferable because it conforms to the low to high layout of the pitches both in the grid and in the octave scale that prefaces the examples. Proceeding thus yields d, e and f\#; we are free to prefer B (also, incidentally the 'first $j$ ') to $\mathrm{b}$; and the final a ('the second $\vec{a}$ ) seems secure, so that the only discrepancy between description and example now lies in the very first note of the latter. Everything therefore falls into place, and description and example are reconciled, if we venture one change at the beginning of the example, which is in any case textually defective, and understand 'the first $\vec{a}$ ( $\bar{a}$ $a l-\bar{u} l \bar{a})$ or 'the low $\vec{a}$ ( $\bar{a}$ al-thaqìla) rather than 'the high $[x]$ ' (al-hâadda). The substitution, admittedly, involves changing a word rather than just adding a letter, but can be explained readily enough as involving an inadvertent (and imperfect) substitution, within a context of syntactic parallelism, of the definition of the first note in the preceding interwoven braid example, so that:

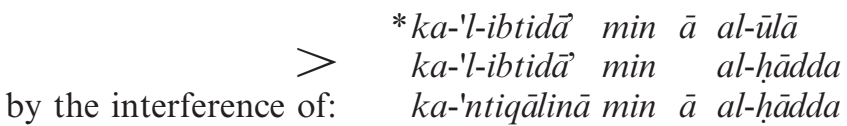


To this may be added, in support of the necessity at this juncture for an editorial intervention more intrusive than merely supplying a missing note, that if the example did originally begin with $k a-' l-i b t i d \bar{a}$ min $\bar{a}$ al-hădda it would be more than a little odd to refer to the same note at the end as 'the second $\vec{a}$ rather than with a phrase including mubtada' ('starting point'), as elsewhere.

Incorporating this emendation, we have the pattern shown in Figure 12. This seems eminently satisfactory, as it fulfils the expectations of congruence between description and example, and clarity and simplicity of visual structure. It allows, in addition, a final move back that is consonant, an attribute al-Kindī is at pains to emphasize, and it could, further, be extended over a second octave or, if so desired, reversed to give the same set of moves in descent. ${ }^{28}$

It remains to note that a rather different interpretation was proposed by Zakariyyā Yūsuf (1962b: 16), who postulated that the relationship between the interwoven and the separate braids was exactly the same as that between the two forms of spiral, one thus being the reverse of the other. His version therefore serves as a direct transition to a consideration of the structure of the interwoven braid. The shape suggested is shown in Figure 13. Although not without interest, this is sufficiently quirky to be discounted without being subjected to detailed scrutiny. It is evidently intended as a combination of, or compromise between, the very different pitch sets of the two examples, but for neither type does it provide a convincing shape, and for the separate braid it

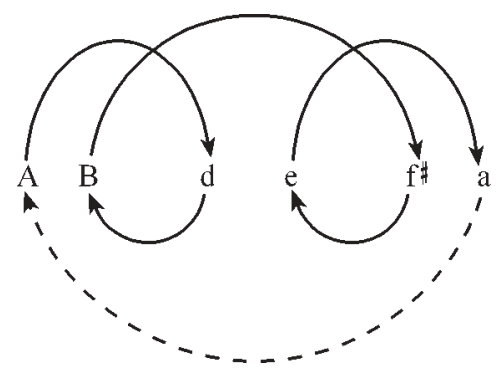

Figure 12.

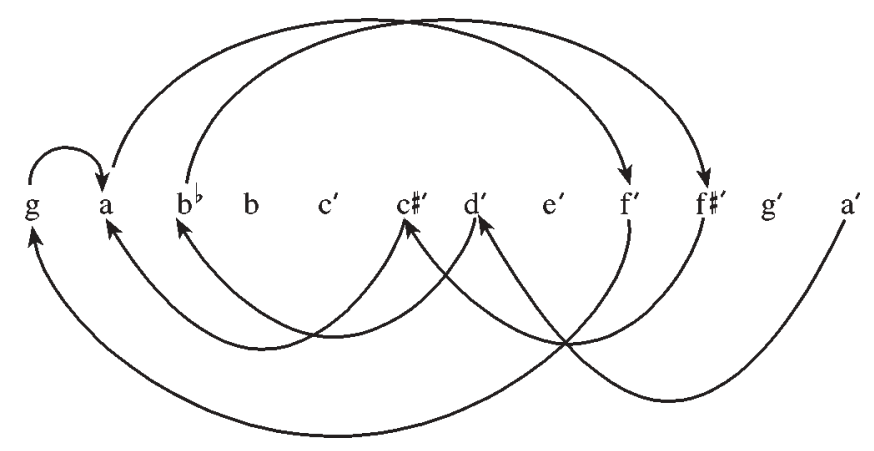

Figure 13.

\footnotetext{
${ }^{28}$ It is incidentally interesting to compare the suggestions made in Strunk (1998: 65) for the kind of structure implied by 'succession' in Aristides Quintilianus.
} 
requires the use of four pitches absent from the example. That the relationship between the braid forms might parallel that between the spirals was certainly an idea that deserved exploring, but to be accepted it would have needed to be argued for far more persuasively. ${ }^{29}$

We come back then, finally, to where we began, with the problematic interwoven braid. With regard to its putative shape, if it is possible to conclude that a simple succession of loops was the structure probably intended by al-Kindi for the separate braid, we might anticipate in this case a possibly more complex but still relatively straightforward and predictable series, the contrast in terms pointing, perhaps, towards the presence of overlapping loops. As before, the structure proposed by Lachmann and el-Hefni (1931: 13), which does in fact incorporate such loops, is inherently attractive as a shape (and fits exactly the pitch specifications of the example) (see Figure 14):

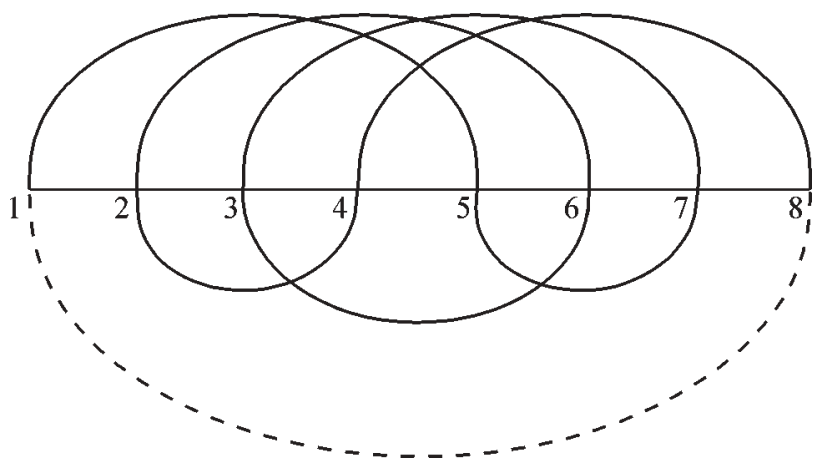

Figure 14.

The notes referred to by the numbers are:

$$
\left.(1=) a^{\prime} \quad \text { a }\right)^{\prime} \quad f^{\prime \prime} \quad f^{\prime} \quad d^{\prime} \quad \text { cł } \quad \text { b } \quad g(=8)
$$

which accordingly occur in the order:

$$
\text { a' d' b) f" ct' a } \text { a }^{\prime} \quad \mathrm{f}^{\prime} \quad \mathrm{g}
$$

thus again prefiguring the notated versions offered by al Faruqi, Yūsuf Shawqī and Zakariyyā Yùsuf. In relation to the example it equates 'high $\bar{a}$ ' with a' and then proceeds according to the logic:

'first $x$ ' means 'the first instance of $x$ encountered in the grid when descending from a'.

This yields d', b', f"' and $\mathrm{f}^{\prime} . h$ and $l$ are without a qualifying adjective, and could therefore be cl' and a)' respectively, but the reading of the final 'second $k$ ' as $g$ is secure.

Thus as an interpretation of the notes mentioned in the example, Figure 14 cannot be faulted. What it does not do, however, is take account of the explicit following phrase 'and so on until the braid is complete'. Rather, it is itself complete and closed, with the further result that there is no engagement with the very peculiar nature of the pitch set used, ${ }^{30}$ which might conceivably have

${ }^{29}$ Al Faruqi (1981: 107) seems to suggest range as a criterion distinguishing the two types one from the other, the separate braid being confined to one octave, the interwoven not. This may be regarded as a shot in the dark.

${ }_{30}$ Save for the dry observation that these pitches 'sind schwer in eine der anerkannten Leitertypen einzuordnen' (1931: 12). 
been rendered less so had the series somehow been continued and gaps filled. Nor is any consideration given to the explicit (and possibly related) link between the interwoven braid and the 24-note grid. More concretely, it runs into trouble when it is collated with the description. This requires that the third note should revert to 'the area of the first', whereas here it goes further away from it; and that the fourth note should be 'beyond its end', a condition which only special pleading could allow $f "$ ' to fulfil. In short, given the apparent impossibility of meeting the conditions of both the description and the example, Lachmann and el-Hefni have simply plumped for the latter, but without indicating how the required continuation should look.

As a result we are still left without a convincing solution. Moreover, given that only minor textual adjustments are required to bring the descriptions and examples of the other non-consecutive structures into alignment; that the resulting structures carry conviction; that they fall within the span of a fifth or an octave; and that there is nothing untoward about their pitch sets, the interwoven braid appears by contrast quite alien, and its oddity is further underlined by the fact that it also flouts the norms of melodic evolution previously laid down by al-Kindì. But the obvious conclusion, that we are faced here with a case of textual corruption, is difficult to sustain, most obviously because the relatively trouble-free nature of the text for the preceding types makes it unlikely that the account of the interwoven braid should suddenly be characterized by a markedly higher level of error. If one considers the most obviously problematic aspect, the pitch set, where the text specifies a, b', ct, d, $\mathrm{f}, \mathrm{f} f, \mathrm{~g}, \mathrm{a}$ (or their a' ... a a' octave equivalents), two alterations would be needed to arrive at the unlikely chromatic scale a, c, c*, d, f, f*, g', a', while three would be needed to arrive at either a, b, cł', d', e', f'”, g', a' or a, b', c', d', e', f', g', a', and yet another to confine the series within a single octave, and all this without making much better melodic sense of the ensuing sequence of intervals. But even to contemplate such emendations is, it may be argued, to misconstrue the singular status of the interwoven braid, which al-Kindi himself marks off from the previous types by associating it, uniquely, with the grid.

This, evidently, is part of the problem. For example, one might wonder why, if the interwoven braid were conceived, like the separate braid, in terms of a single octave, it should need to be accompanied by an elucidatory grid spanning two octaves, and non-identical ones at that; why, if the interwoven braid were diatonic, the grid should require extra pitches; and, more fundamentally, why the interwoven braid should need this adjunct at all. Assuming that the entries in the grid are not also full of errors it could not have worked effectively as a transposition aid, and for this purpose the imbalance between the two octaves would in any case be an illogical asymmetry-this quite apart from the fact that there would have been no reason to provide such an aid only for the interwoven braid when transposition would presumably be possible for all structures. It thus seems best to begin by taking the grid at face value and accept that it was meant to serve exactly the function al-Kindi ascribes to it, being designed to provide enough extra information to allow the most complex of the non-consecutive movements to be worked out fully, the implication being that in the process it would extend beyond the confines of a single octave. ${ }^{31}$ The problem remains, however, that it is by no means easy to see how

\footnotetext{
${ }^{31}$ Consequently, there seems no pressing need to emend hattā yu'tā 'alā nagham al-jam' in the description to conform to the equivalent hattā yu'tā 'alā àkhir nagham al-jam' in the description of the munfașil.
} 
it could fulfil this function. For example, if we revert to the structure proposed by Lachmann and el-Hefni and plot the pitches of Figure 14 spatially on to the grid (keeping the right to left disposition of the original) in their order of occurrence, we arrive at the model shown in Figure 15.

$\begin{array}{llllllll}\bullet & \bullet & \bullet & \bullet & \bullet & \bullet & \bullet & \bullet \\ 8 & \bullet & \bullet & 3 & \bullet & \bullet & 5 & 2 \\ \bullet & \bullet & 7 & 4 & \bullet & 6 & 1 & \bullet\end{array}$

Figure 15.

It is immediately apparent that there is no pattern here that could be continued so as to fill in the other positions. Ironically, assuming it to be a condition that no pitch should be repeated, the simple loop structure argued for in relation to the separate braid can easily be projected onto, and continued over, the whole grid, but the more complex double loop suggested by Lachmann and el-Hefni cannot. Also evident from Figure 15 is the unexpected omission (in descent) of the very first note ( $\mathrm{b}^{\prime}$ '). Now, if we go back to the example and interpret 'first $x$ ' to mean not specifically 'the first instance of $x$ encountered in the grid when descending from a" but generically 'the first instance of $x$ encountered in the grid when descending (i.e. from the highest pitch)', for 'first $b$ ' we will have b' instead of b', thus both filling the top slot and at the same time, importantly, heeding the condition of the description that the third note should revert to the area of the first. With this change in interpretation we obtain the shape in Figure 16, which is rather more satisfactory in terms of filling in neighbouring slots in the grid, despite there remaining three still unaccounted for within the area $c t^{\prime}-b{ }^{\prime}$. On the obvious assumption that the leap from $\mathrm{f}^{\prime}$ to $\mathrm{g}$ takes us to the point where the previous set of moves is repeated, we find that the end result would fulfil two basic expectations, as it covers the range of pitches set forth in the grid from end to end and provides a consonant final move back to the beginning. But it is still some way from being a convincing solution: there is an unnecessary and inexplicable gap in the middle (from a to $c^{\prime}$ ); and the general shape, although combining familiar elements of loop and spiral, is rather more complex and asymmetrical than one would have anticipated, both by comparison with that suggested for the separate braid and, especially, when set against the very basic set of moves adumbrated in the description.

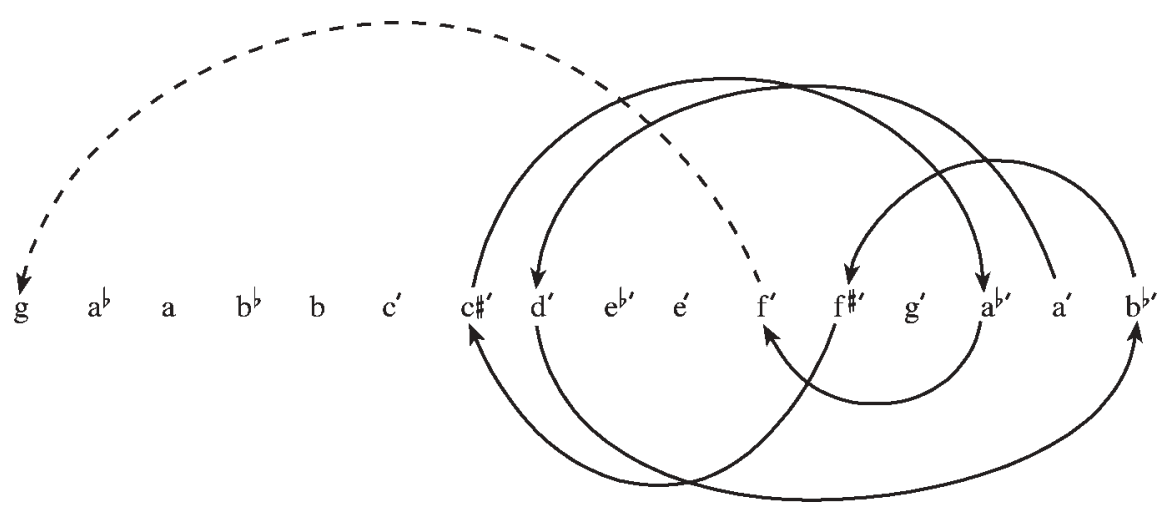

Figure 16. 
In contrast to the separate braid, where the five moves of the description neatly match the six notes of the example, with the interwoven braid there is no such direct correspondence: eight pitches are specified in the example, but the description mentions only three moves. However, on the assumption that the two relate to each other in a transparent way, one obvious conclusion would be that the example illustrates a two-fold application of the moves in the description, and although Yūsuf Shawqī (1969: 184) does not adduce this particular argument, he does derive from the mirror symmetry of the visual extrapolation proposed by Lachmann and el-Hefni the idea that the example of the interwoven braid is made up of two parts, the first consisting of the first four notes, the second of the remaining four. But nothing is said about the internal logic of their structure or how they might correspond to each other, so that no clue is given as to a possible continuation, and there is no reference to the ways in which each segment might or might not correspond to the moves specified in the description. These imply, if anything, a simple back and forth shuttling motion; indeed, of the various possible configurations that can be derived from them, $4,2\{3,1\}$ would produce exactly the simple loop shape proposed in Figure 12 for the separate braid. But the one that fits the first four notes of Figure $16\left(\mathrm{a}^{\prime} \rightarrow \mathrm{d}^{\prime} \rightarrow \mathrm{b}^{\prime} \rightarrow \mathrm{f}^{\prime \prime}\right)$ is $2,4\{1,3\}$, and if repeated from $\mathrm{f}^{\prime \prime}$ it also fits the next set of four $\left.\left(\mathrm{f}^{* \prime} \rightarrow \mathrm{c}^{\prime \prime} \rightarrow \mathrm{a}\right)^{\prime} \rightarrow \mathrm{f}^{\prime}\right)$. A further attractive property of this division is that, when considered in relation to the notes specified (that is, discarding any intermediate pitches listed in the grid), it gives for the first set of four the moves $-4,+5,-3$, and for the second $-3,+4,-2$. For what it is worth, this can be read as a fit of sorts between the description and the example as interpreted here, and it is also in accord with the understanding of the final $\mathrm{g}$ as representing a jump to the point where the process may recommence. But although this interpretation effects some sort of reconciliation between the two related passages, it still fails to derive from them a fully convincing structure, to justify the odd selection of pitches in the example, and to account adequately for the function and puzzling attributes of the grid.

Setting aside for a moment the matter of the number and identity of the pitches included in the grid, we may consider first a more fundamental question: what kinds of pattern are possible conditional upon all slots being filled, and no pitch being repeated? Simple arithmetic dictates that the segments would need to consist of $12,8,6,4,3$ or 2 notes, of which the last two can be discarded on the grounds that the example implies something more substantial. If we take as the closest to it a potential pattern of eight notes (although the general argument applies to all segment sizes) we can readily see that under the conditions imposed all eight contiguous notes within a segment need to be included before proceeding further. In relation to the grid the most obvious disposition for a block of eight notes is linear, so that each horizontal line would be exhausted before moving on to the next. The closest possible shape to that suggested in Figure 16 would involve, starting from the first (or last) note but one, the moves $-5,+6,-4,-3,+5,-3$ and +2 , the resulting descending arrangement of pitches in the upper segment being $\mathrm{a}^{\prime} \rightarrow \mathrm{e}^{\prime} \rightarrow \mathrm{b}^{\prime} \rightarrow \mathrm{f}^{\prime \prime} \rightarrow \mathrm{e}^{\prime} \rightarrow$ $\mathrm{a})^{\prime} \rightarrow \mathrm{f}^{\prime} \rightarrow \mathrm{g}^{\prime}$. This differs from the example in only three places, having e' for $\mathrm{d}^{\prime}$, e $\mathrm{l}^{\prime}$ for $\mathrm{ct}$ ' and $\mathrm{g}$ ' for $\mathrm{g}$, but given the nature of the letter shapes involved it would be difficult to make a good case for altering the text to yield e' and e', while the octave shift would also be difficult to justify. There are thus insufficient grounds for arguing that this is what al-Kindi intended.

One might then entertain the thought that if following a predominantly descending layout has failed to provide a satisfactory answer, a solution should be sought along the lines of that proposed for the separate braid, that 
is, by inverting the definition of 'first' to 'first in ascent'. But this time the perhaps more obvious reading provides no ready answer. It would fix $d, b$, f $\mathrm{f}$ and $\mathrm{g}^{\prime}$, and allow $\mathrm{c}$ and a), and to avoid the disturbingly large initial leap from a' to $\mathrm{d}$ it would certainly be possible to understand the 'high $\vec{a}$ as a. However, nothing is gained: the three lowest pitches would remain unaccountably absent, and if the series were repeated after the leap from $\mathrm{f}$ to $\mathrm{g}$ ' there would be no final consonant interval. The result would bring us no nearer the goal of finding a pattern which could be repeated in a way that rendered explicable, or indeed constituted, whatever underlying logic the grid might have, and there is no reason to prefer it to the interpretations proposed in Figures 14 and 16.

In the absence of a convincing solution based on repeating segments of eight we are also no nearer an answer to the question why there are 24 entries in the grid, necessitating the inclusion of pitches additional to those supplied by the lute fretting previously defined, nor to supplementary questions such as why these extra pitches are in the upper rather than the lower register; and why the layout of the grid is not by octaves but by three lines of eight notes each. That such questions are not trivial is shown by the fact that a $3 \times 7$ format would have included all the pitches supplied by the lute without requiring extra frets. The additional notes (a), c*', f*') would all be produced on a fret placed between the first finger fret and the open string, but the equivalent ones in the low register, $B$ i and e), fail to appear. ${ }^{32}$ These additional notes, elsewhere discounted as not used in practice, could have come about as the consequence of an arbitrary decision to extend the number of potential pitches to 24 , but it is safer to assume that they were of some structural significance, although in what way has hitherto remained unclear. By including pitches for which there was no fret on the lute the grid may be thought to emphasize the status of the interwoven braid as a purely notional construct, but however recondite it may have been the suspicion remains, in the light of the very straightforward and readily comprehensible choices of pitches in all the other examples, that there is some as yet unexplained rationale for what appears here to be a random and bizarre selection.

One hypothesis that might be entertained in this respect is that the grid needs to be viewed not as a purely theoretical game board but as an odd mixture of the abstract and the concrete, and that incorporated into the way the interwoven braid relates to it is a hierarchical, practice-based distinction between registers that contemporary musicians associated with the lute. On this view it is the higher register (which occupies two of the three ranks in the grid) that is the more significant, reflecting both its more frequent use as the carrier of melodic material ${ }^{33}$ and the corresponding pre-eminence attached to it in the theorization of mode among practitioners. ${ }^{34}$ Accordingly, we may explore the assumption that ranks two and three constitute the area within

\footnotetext{
${ }^{32}$ Properly speaking two extra frets are needed, one at a limma (90 cents) for a), the other at an apotome (114 cents) for c $c^{\prime \prime}$ and $f^{*}$, with a corresponding multiplication of unused possibilities, the exploration of which would, however, be pointless here.

${ }^{33}$ Shown most clearly by the fact that al-Kindi himself refers to the retuning of the lowest string according to mode, to support melodically prominent pitches in the upper register (Shiloah 1974: 190-1). In addition, Ibn al-Munajjim refers to $f^{\sharp}$ (on the mathlath) as little used and to c (on the bamm) as not being used at all (Neubauer 1994: 394).

${ }^{34}$ Neubauer (1994: 390-8) reviews the relevant source material and, in an area where various interpretations have been proposed, argues cogently that in each of the eight modes the octave which can be derived from Ibn al-Munajjim's text extended down to f", f or e on the mathlath. But that we are dealing with normative octave structures is a presumption, and even on this reading it is still the $\mathrm{g}-\mathrm{f}^{\prime}$ register on the mathnā and zìr strings that predominates in establishing them.
} 
which the braid pattern is worked out, with the first rank being merely a passive reflection of the existence of the two lowest strings of the lute, its eight entries doing no more than faithfully record all the pitches produced on them with the usual fretting, save only for the khinsir note on the mathlath (g), which would normally be played on the open mathna string and is therefore placed at the beginning of the second rank. This and the third rank include, in addition to the notes of the two higher strings, those of the theoretical fifth string, thus allowing for the development of the braid pattern upwards over a range of more than an octave, but it is indicative that the notes of the fifth string do not go beyond the natural limit of the khinsir fret, and thus contrast with the further extension required in the earlier treatment of the systema teleion. Such is not to argue that the interwoven braid itself is any less abstract than before, but merely to suggest that its field of play is partially a real one, albeit slightly enlarged by the addition of extra notes, and is governed by the dynamics of practice, which place the two lowest strings in a subordinate role. If, then, the game is played out on ranks 2 and 3, and the example is interpreted as ascending, in parallel to what, it has been argued, is the most cogent account of the separate braid, we may consider the 'first $x$ ' to mean 'the first $x$ to be encountered when ascending from a', and consider the initial 'high $\vec{a}$ to be a. Disregarding for the moment the final note, this will yield the pattern shown in Figure 17. This interpretation of the example provides a simple and clear overlapping loop pattern, albeit one that, if continued with the same moves as at the beginning, would, as the dotted projection suggests, go off the grid after f', and here we need to take account of the final note in the example ('the second $k^{\prime}$ ). If it is accepted that notes are defined as ascending from a there is just one instance of $k$ above ( $\mathrm{g}$ '), so that the qualification 'second' only makes sense if one does in fact continue beyond the confines of the third rank of the grid and circle back to the second, thereby allowing a repeat of the whole sequence..$^{35} \mathrm{~g}$ is the first note of the second rank (equivalent to the open mathna string), and replaying the same series of moves from here has the interesting effect of filling several of the empty slots, so that there is now no unused pitch between $g$ and $\mathrm{g}^{\prime}$, and the interweaving of the two strands corresponds exactly to the concept of 'plaiting' intrinsic to dafir.

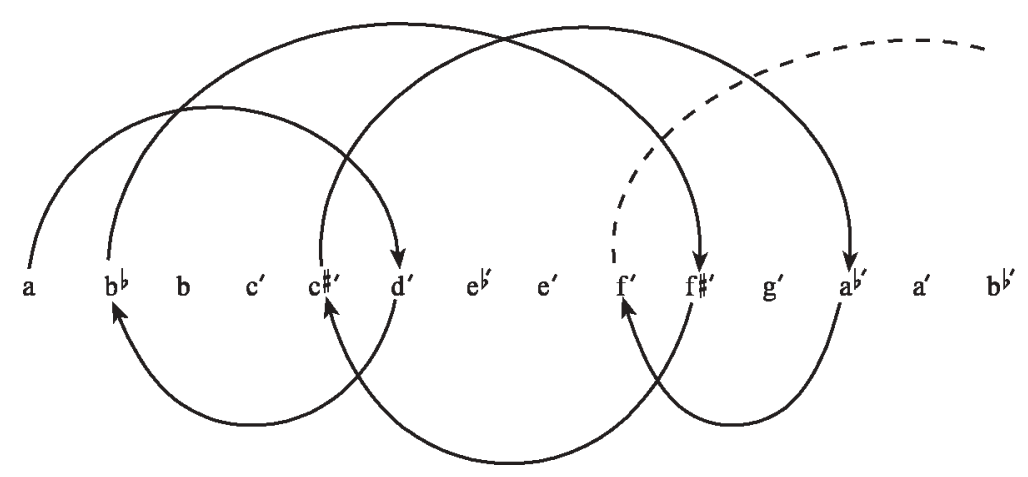

Figure 17.

${ }^{35}$ To the extent that this is a plausible interpretation it could also account for the inclusion of the qualifier 'first' before $w, y$ and $t$ which, in relation only to ranks 2 and 3 , where there is one example of each, is logically redundant. It makes sense, however, if it has the function of excluding the possibility of jumping beyond rank 3 and circling back. 
As a solution, however, this is not necessarily compelling, for not everything has been accounted for. The symmetry and exhaustiveness that it seems to imply are not fully worked out; three pitches remain unused; and there is one overlap, f"' being shared by the two series. But these defects, if such they are, could be remedied quite readily by adjusting the example towards the end to include a mirror inversion of the initial moves, whereby instead of:

$$
\begin{array}{llllllll} 
& +5 & -4 & +8 & -5 & +7 & -3 & \\
\text { we would have: } & +5 & -4 & +8 & -5 & +8 & -4 & +5
\end{array}
$$

as a result of which all the pitches in ranks 2 and 3 are included and none is used more than once, as is shown in Figure 18 (where the two series are given on separate lines for the sake of clarity).

In favour of such extrapolations could be urged al-Kindī's tendency to provide sufficient information for the correct inferences to be made rather than to work out structures exhaustively. With the two types of spiral, for example, the description gives a basic set of directional instructions which are then clarified and reinforced by the pitch specifications of the example, but the logical point at the centre to (or from) which the movement proceeds is simply omitted. By analogy, one could think of the elliptical description of the 'interwoven' braid as setting us on the path by indicating the fundamental type of manoeuvre to be used, and of the example as providing further extension: neither actually completes the process, a point that is expressly made in the wording of each.

How they relate to each other, however, is again seemingly problematic. It was noted in relation to Figure 16 that the moves represented by the first four notes also fitted the next four, but here (as also in Figure 17) the connection between description and example is not of the same order. The initial fit is fine: $\mathrm{a} \rightarrow \mathrm{d}^{\prime} \rightarrow \mathrm{b} \rightarrow \mathrm{f}^{\prime \prime}$ embody the three moves of the description perfectly (here in the form $\{1,3\} 2,4)$, with b) returning to the 'area' of a. What is not so clear is where the next set of moves should begin. If, as before, from f"', we would have $\mathrm{f}^{\prime \prime} \rightarrow \mathrm{c} \sharp^{\prime} \rightarrow \mathrm{a}^{\prime} \rightarrow \mathrm{f}^{\prime}$ (and similarly, in Figure 17, $\left.\mathrm{f}^{\prime \prime} \rightarrow \mathrm{c}^{\prime \prime} \rightarrow \mathrm{a}\right)^{\prime} \rightarrow \mathrm{f}^{\prime}$ ), which, with its initial downward move, could only be understood as proceeding in reverse $(2,4\{1,3\})$. A rather better fit, it could be argued, would be gained by beginning again either from the next note, $\mathrm{c}^{\prime \prime}$, even if the case for $\mathrm{f}^{\prime}$ being in its 'area' may not be very strong, or, odd as that may seem, from the penultimate b) of the first block of four. But the continuation beyond the second block would again have to be downwards, contrary to the terms of the description, while if the second block begins from cł' we certainly have initial forwardbackward moves, but the third note can only parallel that in the first block by going 'beyond the end' of the third rank of the grid, to locate a new initial point at the beginning of the second rank (in which case the description could even be adduced in favour of the extension proposed in Figure 18).

The problem is resolved rather more easily, though, if we interpret the description not as a block of three moves producing the outline of a set of four notes that fails to indicate clearly how to continue thereafter, but as a terse and yet precise encapsulation of the relative positioning of pairs of notes, whereby the first move represents the first pair, the second indicates that the next pair begins between the notes of the first pair (and in the proximity of the first note), and the third that it ends beyond them, thus producing a series of loops. The only imprecision is that with its laconic definition of just three forwardbackward-forward moves, the description could just as well fit the shape proposed for the separate braid in Figure 12. However, if we accept that what is exemplified in the separate braid is a string of simple loops, it is reasonable 


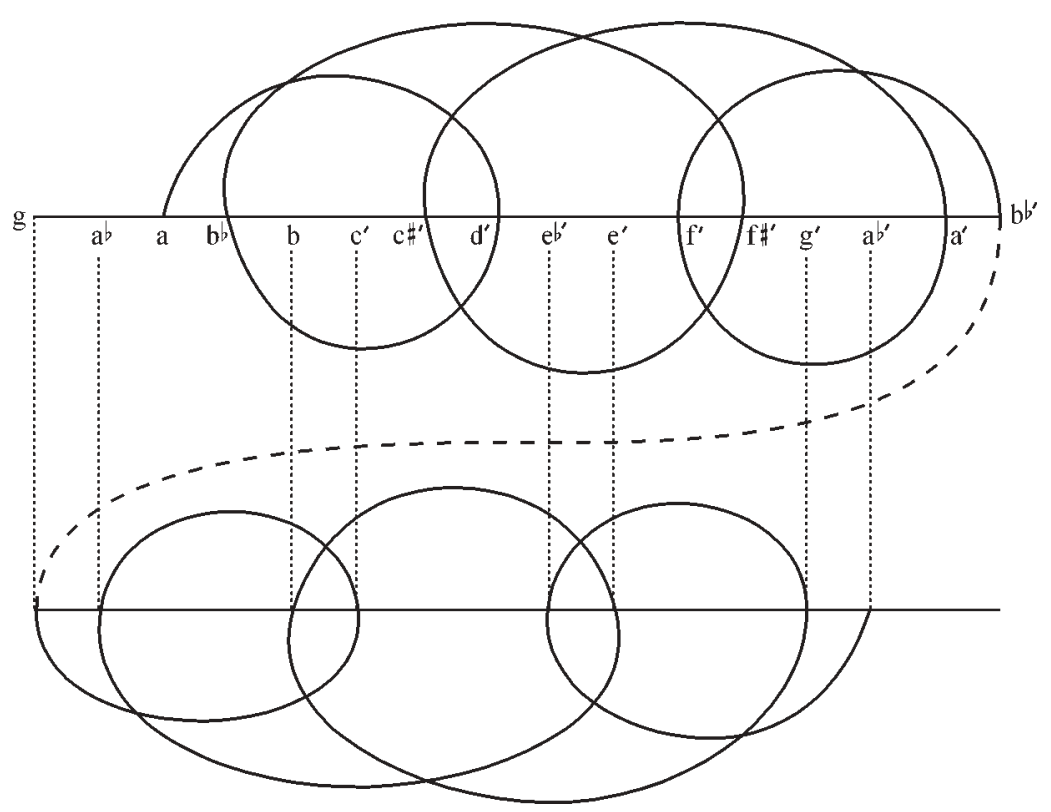

Figure 18.

to assume that al-Kindi disregarded that possibility for its interwoven counterpart, and felt no need to spell out the difference by tightening up the description. The distinction would in any case be supported by the semantic contrast between munfasil and mushtabik, especially when the series is extended, as suggested in Figure 18, to produce a second interwoven layer.

Thus according to this reading the extrapolation proposed in Figure 18 does not conflict with the moves described. Where it fails, rather, and blatantly so, is in running counter to al-Kindì's insistence that the final interval marking the return to the initial note should be consonant. Whether one takes just the first full statement of the braid, which implies a return from bi to a, or both statements together with, therefore, a final return to a from a', no such consonant interval is forthcoming. Given this particular but crucial defect, there is no strong case to be made for Figure 18 as a precise representation of al-Kindī's intentions (and for seeking to amend the text of the example accordingly).

We return, then, to Figure 17, with its variable loops. These, it was noted, would produce a less than perfect fit when repeated in a second series. But given that the variations in size appear inconsistent or, perhaps more precisely, that variation is allowed for by the general nature of the directives in the description, it is legitimate to argue that those in the first series would not necessarily be replicated exactly in the second, and if we wish to be governed by the principles of filling in unused slots wherever possible and avoiding internal repetition, we may easily account for everything but the highest pitch by making just one alteration to the moves on their second appearance, changing:

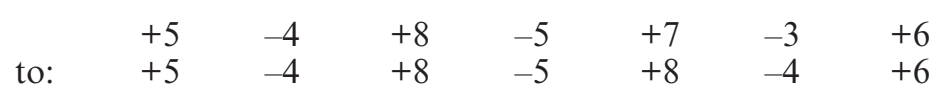

If we again plot these moves on to the grid, indicating the second set in italic, we arrive at the pattern shown in Figure 19. 


$\begin{array}{llllllll}\dot{8}=1 & \mathbf{3} & \boldsymbol{\bullet} & \bullet & \bullet & \bullet & \bullet & \bullet \\ 7 & 4 & 7 & 3 & 5 & 2 & 5 & 2\end{array}$

Figure 19.

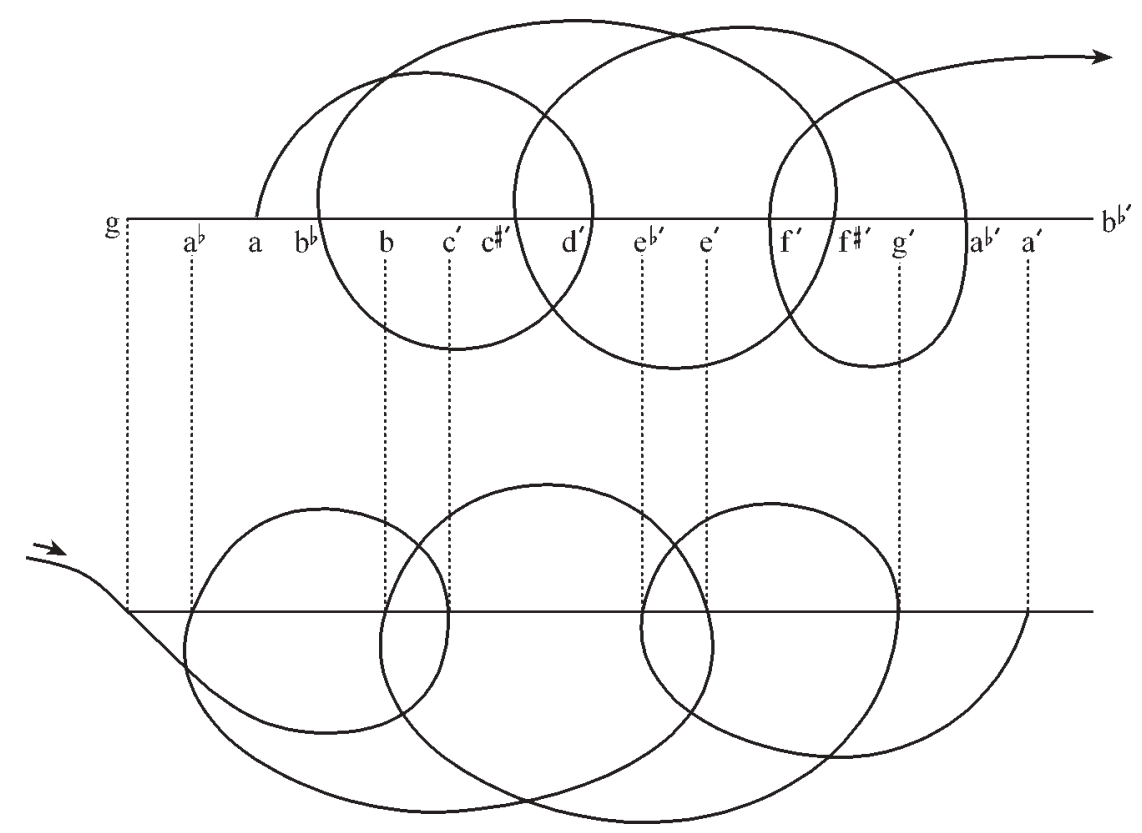

Figure 20 .

Displayed spatially, this yields the pattern shown in Figure 20. The neatness of the intermeshing between the two series, which provides an even stronger reading of mushtabik, is inherently attractive, and considering them as a plaited compound also helps provide a simple, if unexpected, solution to the puzzle of the bizarre nature of the pitch set presented in the example: it would, on this interpretation, simply be void of meaning, and consequently would cease to be a puzzle. It would have nothing to do with the chromatic (or indeed any) genus, but just be the arbitrary product of an interlocking pattern of moves imposed upon a linear series of pitches, the ensuing intervallic relationships being incidentally generated epiphenomena.

There is, no doubt, a strong element of conjecture in Figure 20. But it does no violence to al-Kindî's text; it respects and consistently applies the sequence of moves laid down in the description; it preserves all the pitches cited in the example; and it concludes with a consonant return to the initial note, in fact with the most consonant interval possible. With regard to the one outstanding issue, the omission of the highest pitch, we may refer once more to the underlying relationship of the grid to the lute, and note that $b^{\prime}{ }^{\prime}$ is asymmetrical, intrusive even, to the extent that it is the only pitch in ranks 2 and 3 requiring the khinsirir fret (the others it could produce, $\mathrm{c}^{\prime}$ and $\mathrm{f}^{\prime}$, can equally well be played on open strings). It is not unreasonable to think of the field of play of the interwoven braid being conceived not just generally in terms of ranks 2 and 3 
as representative of the pitch resources of the three highest strings, but also specifically in terms of the 15 notes available on them without the use of the khinsirir fret. The implication is, therefore, that the $b^{\prime}$ is a makeweight, its inclusion dictated by the need to have a parallel eight entries in rank 3. Concerning the underlying relationship between grid and lute fretting it may also be observed, again without in any way wishing to imply that the braid was anything other than a wholly abstract projection, that it contains a number of fourths (with the further addition of a minor seventh), that is, of consecutive notes that would be produced on the lute by moving from string to string stopping at the same point (see Figure 21).

Irrespective of which particular versions, if any, might ultimately be preferred for the two types of braid from among Figures 11-12 and Figures 14, 15,17 and 20 respectively, one thing they all have in common is the crucial realization that a linear reading of the graphic symbols, that is, as notation, makes little or no sense. ${ }^{36}$ As with the spiral shapes, in order for the patterns they represent to be adequately comprehended they need to be bodied forth in two dimensions as geometrical designs, for although an inkling of the kind of shapes intended is given by the verbal labels, some form of spatial representation is still required to follow the working out of the process; and apart from the basic mutatâli move to the next pitch that is elaborated theoretically to produce conjunct motion over a whole scale, it can be claimed with confidence, despite our general ignorance of the melodic norms operative in ninth-century Baghdad, that in attempting to devise a taxonomy of pitch contours al-Kindī incorporates formal generative processes the outputs of which stand at some

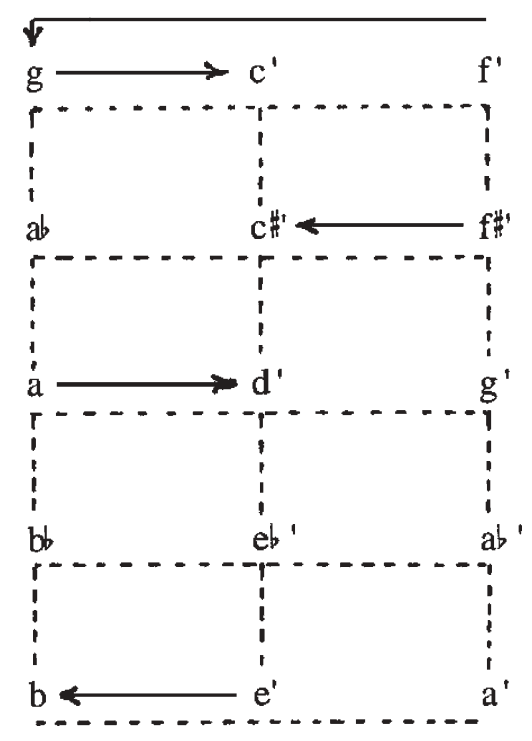

Figure 21.

${ }^{36}$ As before, the one person to confront this problem is Yùsuf Shawqī (1969: 180-8). Recognizing that the products of the various rules as manifested in the examples are not valid melodic structures as they stand, he regards them as skeletal shapes that would be filled in in performance, the notes specified providing 'temporary points of support' (mawādi' al-irtikāz al-mu'aqqata) in what he presumes to have been a predominantly conjunct melodic flow, although, as indicated by the realizations he suggests, he conceives of them primarily as indicating the points at which the melody changes direction. 
remove from anything a composer or performer of the period-or of any other, for that matter-might have produced. In short, whether inherited or devised wholly or in part by al-Kindī, the rules of the game, rather than being auditory and performance-related, are in essence a working out of a visual metaphor. One might wish to seek analogies elsewhere for rigorous structures that are profoundly intellectual and characterized by the detailed implementation of recursive patterns-bell-ringing in English culture and svaraprastāra in Indian come readily to mind-but however specialized and schematic, these can be and are realized in sound. ${ }^{37}$ They are, in short, functional, whereas al-Kindī is engaged in an exercise in abstract typology of little or no relevance to either performers or audiences.

Given that on the intellectual map of Islamic scholarship music (or, more properly, a particular theoretical domain and its related discourse) was located among the mathematical sciences, it would be natural to identify al-Kindīs scheme as having affinities with geometry, a view favoured by Lachmann and el-Hefni (1931: 14), who consequently downgrade the metaphorical autonomy of the terminology. ${ }^{38}$ But there seems to be no good reason for sacrificing one to the other: the metaphorical genesis of these categories is incontestable, and if anything one would wish to reverse the emphasis: geometry in the ninth century meant primarily translation and critical comment on Euclid, a process to which al-Kindì himself contributed. From this perspective the shapes generated by his spiral and braid structures would be decorative but marginal doodles, for they have no connection with the elaboration of Euclidian geometry. It is less the case that geometric figures are given labels which are metaphors than that metaphorical play here takes place within a conceptual domain where reference to geometry might well be expected, but in this particular instance would be of dubious relevance. In the event, a possibly more significant cultural connection, if we recall that the term dafir supplants is muwashshah ('sash'), could be established with fashion, an area that was also a metaphorical recourse for aesthetic discrimination both in music ${ }^{39}$ and literature (Goldziher 1896: 130-1)..$^{40}$

The momentary terminological hesitation between muwashshah and dafir is possibly indicative of a new area of expression with a freshly-coined vocabulary relying on ad hoc invention. But al-Kindîs melodic taxonomy, together with its associated terminology, failed to establish itself as conventional; indeed, it reappears nowhere else. If it relied on a translation rather than excogitation, the text in question seems not to have been known to other scholars working on the Greek legacy. Neither does his own formulation, intriguing as it is, find an echo in later theoretical texts. Al-Fārābī (d. 950), who did not hold al-Kindī in high regard as a theorist, may conceivably have engaged with it in the lost part of the kitāb al-mūisiqu al-kabìr, but al-Kindī's risāla may not have been known to later writers. Both al-Fārābì and Ibn Sīnā (d. 1037) were similarly concerned to provide a systematic topology of melodic structure, and

\footnotetext{
${ }^{37}$ On svaraprastāra it is not necessary to follow the argument of Jairazbhoy (1961) that its influence can be detected in performance: it is sufficient that it is used as a practice technique.

38 'Die Namen der Melodiebewegungen sind nicht lediglich Metaphern, sondern dienen dazu, einen Zusammenhang mit außermusikalischen, und zwar mit geometrischen Bewegungen anzudeuten.

${ }_{39}$ As, for example, in Ibn al-Ṭhḥān, hāwī al-funūn, 29-30.

${ }^{40}$ However, it would probably be too far-fetched to seek for inspiration in this area for particulars, even if stitching could have suggested loop patterns (although according to the technical analyses of tirāz fabrics done by Bellinger (Kühnel 1952: 104) the more complex types seem to be characteristically Egyptian rather than Iraqi).
} 
in doing so invoked geometric categories such as 'straight' (mustaqim), 'circular' (mustadīr) and 'polygonal' (mudalla'). Their vocabulary thus points to a continuing habit of conceiving melodic shapes visually, but it is evident that they were either unwilling to incorporate into their thinking, or were simply unaware of, the singular spiral and braid threads woven by al-Kindī.

\section{Text}

The following text of the relevant section of the risāla incorporates the emendations proposed during the course of the above discussion, namely:

- the substitution of احـدى احسى احسل In the description of the 'outward' spiral

- the substitution of من آ الأولى for من الحادة in the example of the 'separate' braid

Other occasional editorial additions (mostly to bring the syntax in line with normative grammar) are placed between square brackets. All cases of divergence from the original are noted except, in most instances, for: (a) the addition of missing points. In some cases (e.g. $z$ for $\Delta$ ) this is an automatic procedure, but with verbs, occasionally, a choice has to be made between a passive

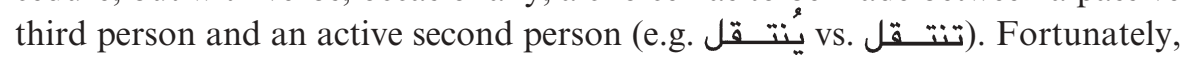
the general sense of the passage is not affected; (b) writing i or $\mid$ or $\_$instead of 1 .

The only punctuation given is that of the original. Layout is used to clarify sentence structure otherwise.

In the apparatus the original is indicated by $p$. Also given are all the readings proposed in earlier editions that differ from those presented here. They are identified thus:

$\begin{array}{ll}\text { Lachmann and el-Hefni } & \text { J } \\ \text { Zakariyyā Yūsuf } & \text { \ }\end{array}$


فأما على كم ضرب يكون اللحن فهو ينقسم أولا قسمين أحدهما

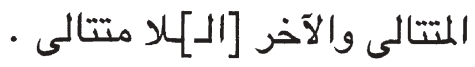

أما المتتالى فكالابتداء من نفمة ثم التزيد في الحدة ألو الثقل الثل على

استقامة

وأما [الـ]ـلا [م-]تتالى فينقسم قسمين أحدهما اللولبى والآخر

الموشح

أما اللولبى فأن يبتدى بنفمة ثم يثنى بنهاية البعد ثم يثلث بالتى

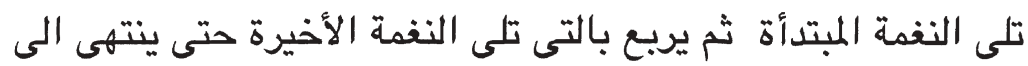

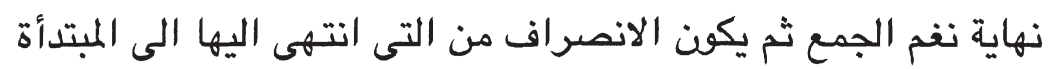

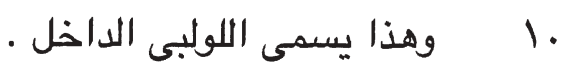

وأما النوع الآخر من اللولبى فأن يبتدأ من هذه النفمة التى التى التى

فرضت أخيرا ثم تكون النقلة منها بالدور كما وصفنا في الذيى قبله

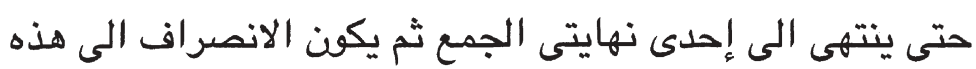

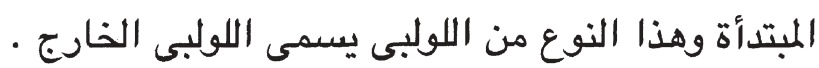

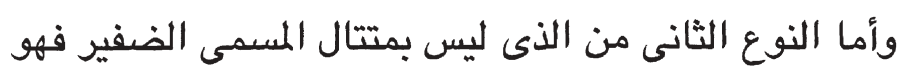

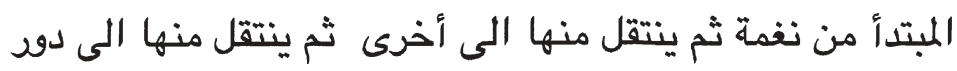
الأولى ثم ينتقل منها الى خلف نهايته ثم كذلك حتى يؤتى على نفم

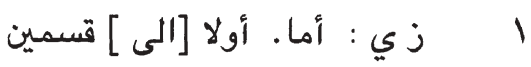

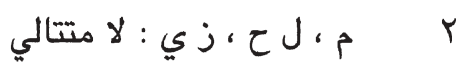

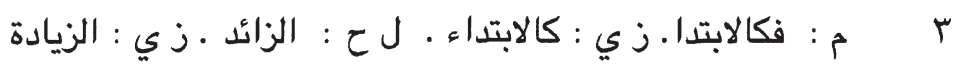

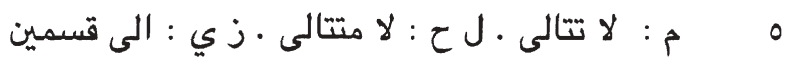

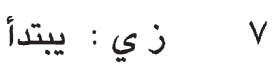$$
\text { م }
$$$$
9
$$

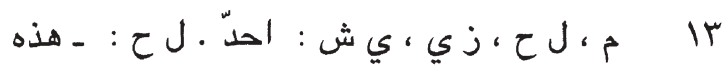

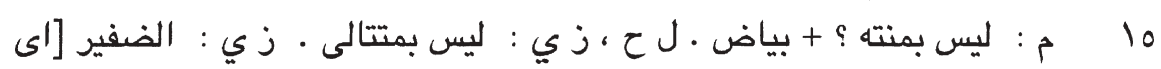

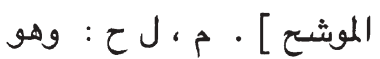

$$
\begin{aligned}
& \text { IV }
\end{aligned}
$$


الب الجمع ثم تكمن النقلة من آخره الى مبتدأه / مؤتلفة .

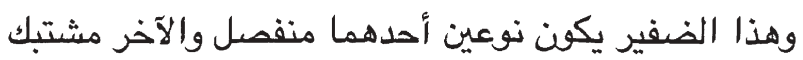

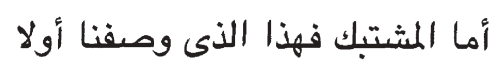

وأمـا المنفصل فأن يبتدىئ من نفمة ثم ينتقل منها الى أخرى ثماثم

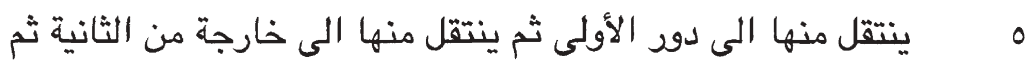

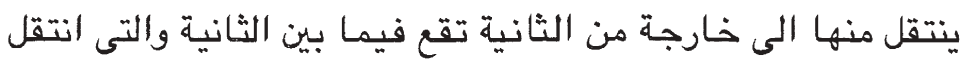

منها ثم ينتقل منها الى خارجة عن التى انتقل منها أيضا حتى يؤتى على

آخر نفم الجمع وتكون النقلة من آخره الى ابتداء النغم نقلة مؤتلفة .

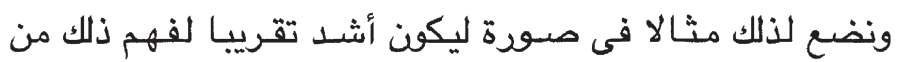

. 1 أنفس المتعلمين ونضع ذلك في الجمع الذى بالكل فئل

\begin{tabular}{llllllll}
\hline & 5 & $b$ & $c$ & $g$ & $s$ & $\rightarrow$ & 1
\end{tabular}

\section{فنفرض النغمة الأولى منه المسبماة المفروضية نفمة آ ومقدمة}

المقدمات جَ والقريبة من مقدمة المقدمات دَ وحادة المقدمات وَّرئيسة

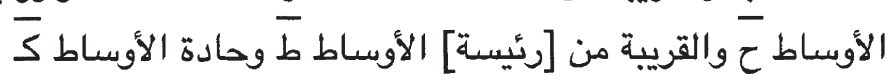

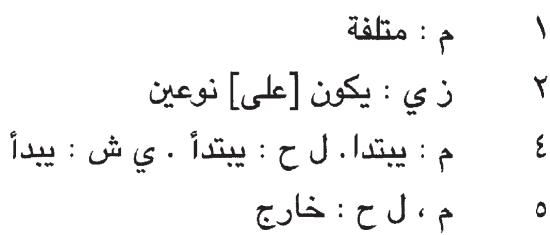

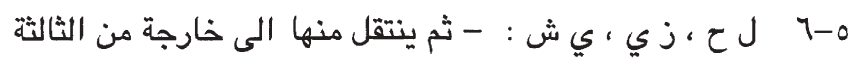
I

V

ي

9

الم :

عا م : من + بياض + الأوساط . مادة الأساط 


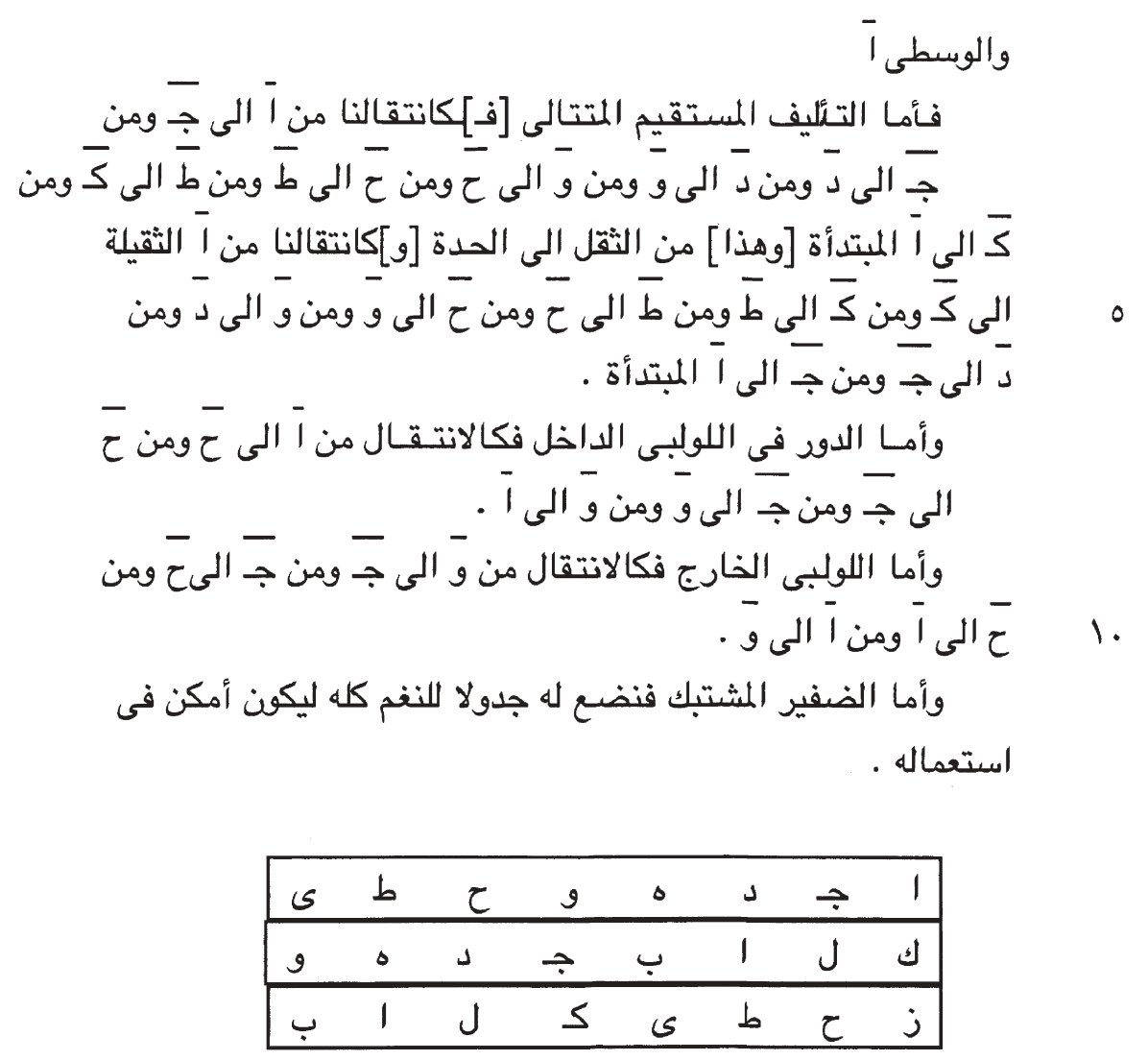

r

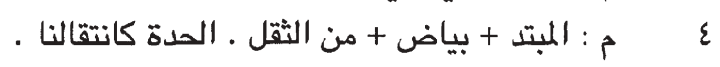

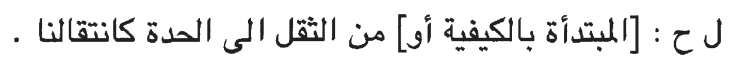

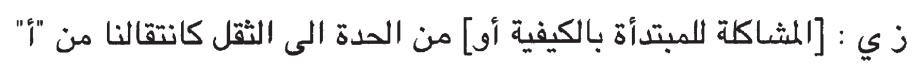
الحادة .

ي ش : المبتداة [بالكيفية]، [أو] من [الحدة الى الثقل] كانتقالنا من "ا" [الحادة]

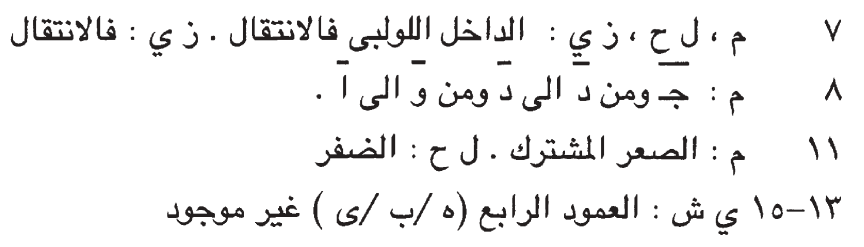



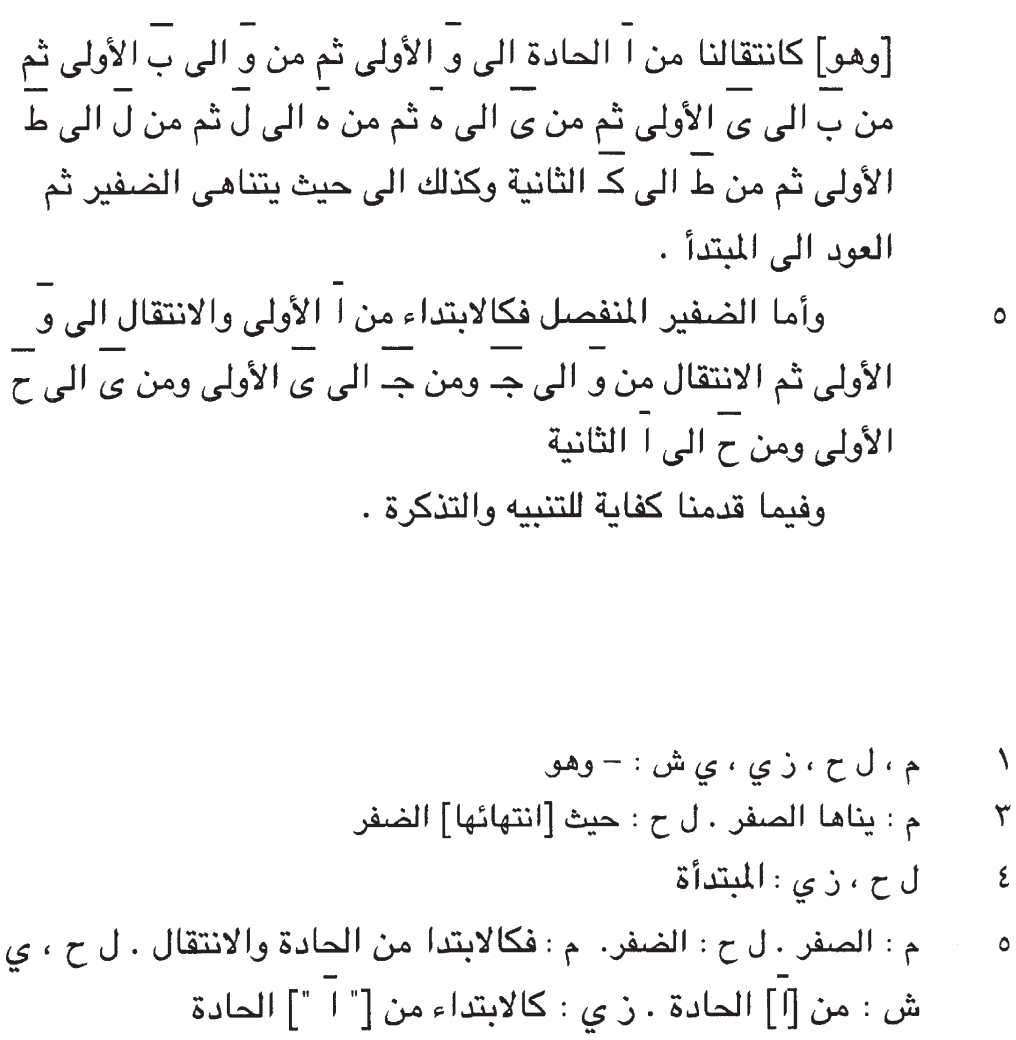

\section{REFERENCES}

Ja'qūb ibn Ishạàq al-Kindī: Risāla fì khubr ta'līf al-alhān. British Library MS Or. 2361, ff. 165-8, and see Lachmann \& el-Hefni 1931, Zakariyyā Yūsuf 1962a, Yūsuf Shawqī 1969, and Cowl 1966.

Ibn al-Ṭahhạān al-Mūsīqī (d. after 1057): hāwwì al-funūn wa-salwat al-mahzūun. Facsimile (ed. E. Neubauer) in Publications of the Institute for the History of Arabic-Islamic Science, Series C, 52, Frankfurt, 1990.

Barker, A. 1989. Greek Musical Writings, II. Cambridge: Cambridge University Press.

Cowl, C. 1966. 'The Risāla fi Hubr Tā'lìf al-'Alḥan of Ja'qūb ibn Ishạā al-Kindī (790-874)', The Consort 23: 129-66.

Farmer, H. G. 1965. The Sources of Arabian Music, 2nd ed. Leiden: Brill.

al Faruqi, L. I. 1981. An Annotated Glossary of Arabic Musical Terms. Westport: Greenwood Press. Goldziher, I. 1896. Abhandlungen zur arabischen Philologie, I. Leiden: Brill.

Jairazbhoy, N. A. 1961. 'Svaraprastāra in North Indian classical music'. Bulletin of the School of Oriental and African Studies 24/2: 307-25.

Kühnel, E. (technical analysis by L. Bellinger). 1952. The Textile Museum. Catalogue of Dated Tiraz Fabrics. Umayyad, Abbasid, Fatimid. Washington D.C.: National Publishing Company.

Lachmann, R. and M. el-Hefni. 1931. Ja'qūb Ibn Ishāq al-Kindī, risāla fì hubr tā’līf al-alhān. Über die Komposition der Melodien. (Veröffentlichungen der Gesellschaft zur Erforschung der Musik des Orients, I.) Leipzig: Fr. Kistner \& C.F.W. Siegel.

Neubauer, E. 1993. 'Der Bau der Laute und ihre Besaitung nach arabischen, persischen und türkischen Quellen des 9. bis 15. Jahrhunderts'. Zeitschrift für Geschichte der ArabischIslamischen Wissenschaften 8: 279-378.

1994. 'Die acht "Wege" der Musiklehre und der Oktoechos'. Zeitschrift für Geschichte der Arabisch-Islamischen Wissenschaften 9: 373-414.

1996. "Al-Halīl ibn Ahmad und die Frühgeschichte der arabischen Lehre von den "Tönen" und den musikalischen Metren, mit einer Übersetzung des Kitāb al-Nagam von Yahyā ibn 'Alī al-Munağğim'. Zeitschrift für Geschichte der Arabisch-Islamischen Wissenschaften 10: 255-323.

Shawqī, Yūsuf. 1969. risālat al-kindī fì khubr șinā'at al-ta’līf. Cairo: maṭba'at dār al-kutub. 
Shiloah, A. 1974. 'Un ancien traité sur le 'ud d'Abū Yūsuf al-Kindī'. Israel Oriental Studies 4: 179-205.

1979. The Theory of Music in Arabic Writings (c. 900-1900). (Répertoire international des sources musicales: B X.) Munich: Henle.

Strunk, O. (ed.). 1998. Source Readings in Music History, revised edition, vol. 1 (ed. T. J. Mathiesen), Greek Views on Music. New York and London: W.W. Norton.

West, M. L. 1992. Ancient Greek Music. Oxford: Oxford University Press.

Yūsuf, Zakariyyā. 1962a. mu'allafät al-kindī al-mūsīiqiyya, ed. Zakariyyā Yūsuf. Baghdad: mațba'at shafíq (risāla fì khubr șinäatat al-ta'lìf, pp. 45-66). . 1962b. müsiqua al-kindī. Baghdad: mațba'at shafíq. 